\title{
AZ ÖNKÉNTESSÉG ALAKULÁSA MAGYARORSZÁGON A 2010-ES ÉVEKBEN - A KÖZPONTI STATISZTIKAI HIVATAL
MUNKAERŐ-FELMÉRÉSÉNEK 2011-2019 KÖZÖTTI
KIEGÉSZÍTŐ FELVÉTELEI ALAPJÁN
}

DOl: https://doi.org/10.53585/OnkSzem.2021.4.3-38

\section{Absztrakt}

A cikk olyan mérési ajánlásokon, tapasztalatokon alapulóan mutatja be a magyarországi önkéntességet a 2010-es években, amelyek világszerte alkalmasak az önkéntes munkavégzés értékelésére, mértékének nemzetközi összehasonlítására. A Központi Statisztikai Hivatal a Nemzetközi Munkaügyi Szervezet, valamint a Johns Hopkins Egyetem által az önkéntes munka mérésére kidolgozott módszertani kézikönyv ajánlásaival összhangban 2011, 2014, 2017 és 2019 években a Munkaerő-felmérés lakossági kikérdezésen alapuló felvételhez kapcsolódóan „Önkéntes munka” címmel kiegészítő felvételeket hajtott végre. Ennek keretében - az önkéntesek demográfiai jellemzőin túl - mind a formális, mind pedig az informális, önkéntesek tevékenységi területeiről, az általuk teljesített órákról, a kedvezményezettjeik köréről, illetve az önkéntesség egyéb jellemzőiről, például a motivációkról képet kaptunk. A kiegészítő felvételek adatai mellett, az önkéntességre fordított idő alapján a becsült egyenértékes létszámadatokat, illetve a becsült értékadatokat is közzétesszük. A becslések elsősorban annak érdekében készültek, hogy számszerüsítsük, milyen mértékben járult hozzá a magyarországi önkéntes munka az ország gazdasági és társadalmi teljesítményéhez. Az adatgyújtés-módszertani azonosságokon túl az óra- és értékbecslések módszereinek változatlanságai is biztosították, hogy az eredmények maradéktalanul összehasonlíthatóak legyenek. A kiegészítő modulok arról tanúskodtak, hogy a felnőtt magyar lakosság jelentős hányada - egyharmada - végzett önkéntes tevékenységet a felvételeket megelőző 12 hónap során, illetve, hogy az önkéntesség össztársadalmi és egyének számára nyújtott hasznossága, a GDP-hez való hozzájárulás pénzben kifejezhető értéke továbbra is igen jelentős.

Kulcsszavak: önkéntesség mérése, informális önkéntesség, formális önkéntesség, önkéntesek által teljesített munkaórák, önkéntesség értéke,

\footnotetext{
${ }^{1}$ Váradi Rita, statisztikus, osztályvezető, Központi Statisztikai Hivatal, Foglalkoztatásstatisztikai osztály
} 


\section{Rita Váradi}

\section{Abstract}

The article presents volunteering in Hungary in the 2010s based on measurement recommendations and experiences that are suitable for assessing the extent of volunteering worldwide and for international comparison In accordance with the recommendations of the methodological manual on measuring volunteering developed by the International Labour Organization and Johns Hopkins University, the Central Statistical Office conducted additional surveys in 2011, 2014, 2017 and 2019 entitled "Volunteering" in connection with the Labour Force Survey based on the population interview. This included, in addition to the demographic characteristics of volunteers, a picture of both formal and informal volunteer activity areas, the hours they volunteer, the range of beneficiaries, and other characteristics of volunteering, such as motivation. Besides the additional survey data, we also publish estimated equivalent headcount data and estimated value data based on the time spent on volunteering. The estimates are primarily designed to quantify the extent to which volunteering in Hungary has contributed to the country's economic and social performance. In addition to the similarities in data collection methodology, the unchanged methods of estimating hours and values ensured that the results were fully comparable. The complementary modules showed that a significant proportion of the adult Hungarian population - one third - had volunteered in the 12 months preceding the survey, and that the benefits of volunteering to society as a whole and to individuals, in terms of the monetary value of the contribution to GDP, remained very significant.

Keywords: measurement of volunteering, informal volunteering, formal volunteering, volunteer hours, value of volunteering,

\section{BEVEZETÉS - KIT TEKINTÜNK ÖNKÉNTES MUNKÁT VÉGZŐNEK A MUNKAERŐ- FELMÉRÉS SZERINT?}

Nemzetközi összehasonlításokban az egyik leggyakrabban hivatkozott statisztikai jelzőszám a foglalkoztatottak száma, illetve a foglalkoztatási arány, mely a fizetett munka megfigyelésére irányul, miközben a közvélemény viszonylag keveset tud arról a hasznos értékalkotó munkáról, amelyre az „önkéntes” jelző alkalmazható. Míg az előbb említett fogalomkörre szinte az egész világon egységesen alkalmazzák a Nemzetközi Munkaügyi Szervezet (ILO), ajánlásait, addig az utóbb említett önkéntes munka számbavétele - a létező nemzetközi ajánlások ellenére sokféle definíció mentén történik, s ez a nemzetközi összehasonlításoknak értelemszerüen korlátot szab. 
Az önkéntes munkavégzés témája ismételten különösen időszerű. A koronavírus-járvány idején ugyanis az önkéntesség több területen is kiemelt szerepet kap. Fokozottan szükség van azokra a formális és informális formában végzett tevékenységekre, amelyek a korábbi években is a legjellemzőbb tevékenységek közé tartoztak a segítséget nyújtók körében (pl. ügyintézés és vásárlás, betegápolás és idősgondozás stb.). Továbbá a 2001-es Önkéntesek Nemzetközi Éve és a 2011-es Önkéntesség Európai Éve után Magyarország Kormánya tizenegy civil szervezet kezdeményezésére - 2021-et az Önkéntesség Magyarországi Évének nyilvánította, mely kezdeményezés a hazai önkéntesség fejlődésének is egy új időszakát indíthatja el.

Ennek kapcsán olyan mérési ajánlásokon, tapasztalatokon alapulóan mutatjuk be a hazai önkéntességet, amelyek világszerte alkalmasak az önkéntes munkavégzés értékelésére, mértékeinek nemzetközi összehasonlítására. A $\mathrm{KSH}^{2}$ ugyanis a Nemzetközi Munkaügyi Szervezet (ILO), valamint a Johns Hopkins Egyetem által az önkéntes munka mérésére kidolgozott módszertani kézikönyv ajánlásait az elsők között adaptálta, s ezekkel összhangban 2011 III. negyedévében a Munkaerő-felmérés (továbbiakban MEF) lakossági kikérdezésen alapuló felvételhez kapcsolódóan „Önkéntes munka” címmel kiegészítő felvételt hajtott végre. Ennek keretében mind a formális (szervezeteken keresztül, szervezetek javára) önkéntes munkát végzők, mind az informális (közvetlenül, nem szervezetekhez kapcsolódó) önkéntesek tevékenységéről képet kaphattunk. A változások nyomon követése érdekében, illetve a Nemzeti Önkéntes Stratégia 2012-2020 időszakra tervezett feladataival összhangban 2014, 2017 és 2019 I. negyedéveiben ismételten ebben a témakörben kapcsolódott kiegészítő felvétel a MEF alap-adatgyújtéshez.

Mind a négy felvételben - a nemzetközi ajánlásokkal összhangban - azokat a személyeket tekintettük önkénteseknek, akik

- közvetlenül vagy valamilyen szervezeten keresztül,

- önszántukból, ingyen, ellenszolgáltatás, fizetség nélkül,

- háztartásukon kívül élő személyek javára, vagy a társadalom (csoport, tágabb közösség, állatok vagy a környezet stb.) hasznára végeztek valamilyen tevékenységet a kikérdezést megelőző 12 hónap során.

\footnotetext{
2 KSH: Központi Statisztikai Hivatal
} 
A három feltételnek együttesen kellett érvényesülni. A háztartáson kívül élő szülönek, gyermeknek, rokonnak nyújtott segítség is beletartozott az önkéntes munkák körébe.

A sajátosságok feltérképezésekor fő elkülönítési szempontnak számított, hogy milyen formában valósult meg az önkéntes munka. Amennyiben az „adakozó”, illetve a „kedvezményezett” között közvetlenül, akkor informális önkéntességröl van szó, ha pedig a kettő közé beékelődött egy szervezet, amelynek a szervezésében, amelyen keresztül vagy pedig javára történt az önkéntes tevékenység végzése, akkor formális önkéntességröl beszélünk.

Az adatgyűjtés módszertani azonosságain túl az óra- és értékbecslések módszereinek változatlanságai is biztosították, hogy az eredmények maradéktalanul összehasonlíthatóak legyenek. Mivel a segítségnyújtás alapérték, a saját háztartásukon kívül élőkre idejüket, energiájukat „adományozók” egy része sokszor nem is gondol arra, hogy segítő tevékenysége egyúttal önkéntes munkának is számít, amelynek mind társadalmi, mind gazdasági szempontból értéke van.

A formális, vagyis szervezeten keresztül, azok javára önkéntes munkát végzők egy része pedig azért marad rejtve, vagy - feltételezhetőn - kerül számbavételre az informális önkéntesek között, mert - annak ellenére, hogy valamilyen intézmény felhívására, szervezésében tevékenykedik - mégsem tekinti szervezettnek ilyen jellegű munkáját. Ennek következtében a formális keretek között önkéntes munkát végzők száma ezekben a lakosság megkérdezésén alapuló felvételekben rendkívül alacsony, a nonprofit statisztikák adataival történö összehasonlításban jelentősen alulbecsült.

Az említett számbavételi sajátosságok, nehézségek ellenére azonban megállapítható, hogy az önkéntesség össztársadalmi és egyének számára nyújtott hasznossága, a GDP-hez való hozzájárulás pénzben kifejezhető értéke továbbra is igen jelentős, és nagymértékben járul hozzá az ország gazdasági és társadalmi teljesítményéhez. A MEF kiegészítő moduljai ugyanis mind a négy alkalommal arról tanúskodtak, hogy a felnőtt magyar lakosság jelentős hányada - egyharmada - végzett önkéntes tevékenységet a kikérdezést megelőző 12 hónap során. Voltak, akik rendszeresen vagy alkalmanként segítettek anyagi haszonszerzés szándéka nélkül, és voltak olyanok is, akik csak egy alkalommal. Munkájukat azonban valamennyien olyan céllal végezték, hogy másokat, egy közösséget segítsenek, vagy egy fontos cél megvalósulását támogassák. 


\section{ÖNKÉNTES MUNKA*}

(i) közvetlenül vagy valamilyen szervezeten keresztül,

(ii) saját akaratból, ingyen, ellenszolgáltatás, fizetség nélkül

(iii) háztartásukon kívül élő személyek javára vagy a társadalom (csoport, tágabb közösség, állatok vagy a környezet stb.) hasznára végzett tevékenység.

*A definíció szerint a háztartáson kivül élő szülő, gyermek, rokon javára végzett munka is önkéntes munkának számít.

\section{ÖNKÉNTESEK*}

Azok a 15-74 éves személyek, akik (i) közvetlenül vagy valamilyen szervezeten keresztül, (ii) önszántukból, ingyen, ellenszolgáltatás, fizetség nélkül, (iii) háztartásukon kívül élő személyek javára vagy a társadalom hasznára a felsorolt tevékenységek közül bármelyiket végezték rendszeresen, alkalmanként, vagy akár csak egyetlen alkalommal is a kikérdezést megelőző

12 hónap során. A rokonok javára végzett tevékenységek is beletartoznak az önkéntes tevékenységek körébe, amennyiben a kedvezményezettjei más háztartásban élnek.

*A definíció szerint a háztartáson kívül élö szülö, gyermek, rokon javára végzett munka is önkéntes munkának számít.

\section{Közvetlen önkéntes munkát végzők}

Azok a 15-74 éves személyek, akik saját szervezésben, közvetítés nélkül végeztek önkéntes tevékenységet a kikérdezést megelőző 12 hónap során.

1. tábla Munkaerő-felmérés kiegészítő felvételeinek

\section{Önkéntességi arány}

Az önkéntesek aránya az azonos korú népességen belül.

\section{Szervezeten keresztül önkéntes munkát végzők}

Azok a 15-74 éves személyek, akik egy nonprofit vagy egyéb szervezetnek, vagy azon keresztül, annak szervezésében végeztek önkéntes munkát a kikérdezést megelőző 12 hónap során. 


\section{A 15-74 ÉVESEK EGYHARMADA VÉGZETT ÖNKÉNTES MUNKÁT}

A hazai önkéntesség számbavételére irányuló felvételek arról tanúskodnak, hogy a 2010-es években átlagosan kb. 2 millió 440 ezer fö, a 15-74 évesek egyharmada végzett valamiféle önkéntes tevékenységet a felvételt megelőző 12 hónap során. Az önkéntesek száma és aránya összességében növekedő tendenciát mutatott, a 2011. évi 28,4 százalékos önkéntességi ráta 2014-ben 5,9 százalékponttal, 2017-ben 8,3 százalékponttal volt magasabb a kezdeti értéknél. 2019-ben ugyan az előző felvételhez képest meglehetősen nagy visszaesés volt tapasztalható, de a kiindulópontnak is tekinthető 2011. évi értéket még így is 4,8 százalékponttal meghaladta az önkéntesek aránya (1. ábra).

1. ábra Az önkéntes tevékenységet végzők számának és rátájának alakulása, 2011-2019 között

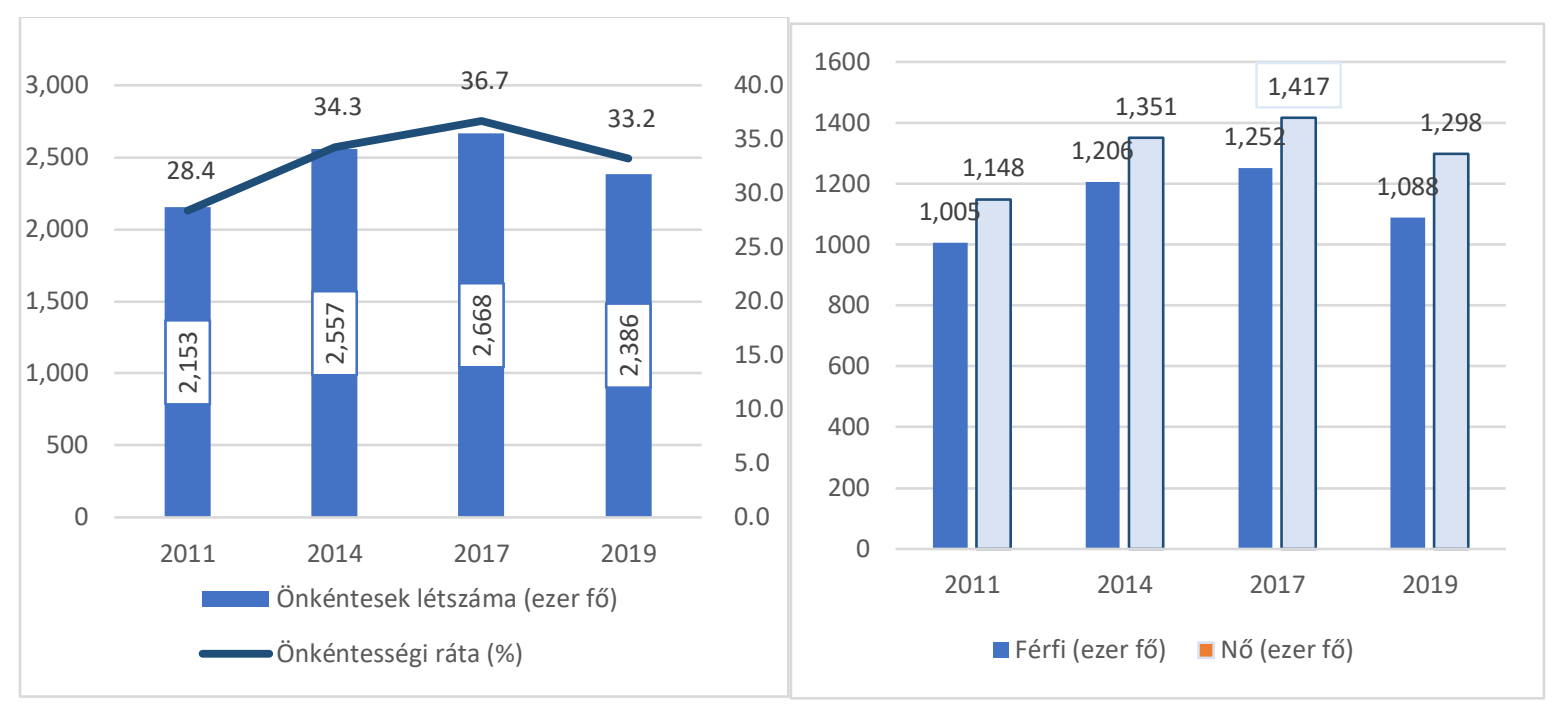

Forrás: KSH, Munkaerő-felmérés, Önkéntes munka c. kiegészítő felvételek 2011-2019.

Ennek ellenére az önkéntesség struktúrájában markáns változások nem történtek; a felvételek eredményei azt mutatják, hogy az önkéntesség leginkább közvetlen segítségnyújtás formájában valósul meg. Az önkéntesek túlnyomó többsége - 89-94 százaléka - közvetlenül segített ingyenes munkájával (ők az informális önkéntesek), szervezet közremúködésével, szervezeten keresztül vagy annak javára 3-8 százalékuk végzett ilyen tevékenységet (ők a formális önkéntesek), míg 2-3 százalékuk közvetlenül és szervezet közremúködésével egyaránt támogatott rászoruló személyeket, különböző szervezeteket, intézményeket vagy valamiféle közös ügyet (2. ábra). 
A közvetlenül, informálisan önkéntes munkát végzők száma 2011 és 2017 között folyamatosan növekedett ( 2 millió 10 ezer föről 2 millió 416 ezer före), és ugyan a 2019. évi felvétel meglehetősen nagy visszaesést mutatott, számuk ennek ellenére 112 ezer fővel meghaladta az évtized elején mért értéket.

2. ábra Az önkéntes tevékenységet végzők megoszlásának alakulása az önkéntesség formája szerint, 2011-2019 között

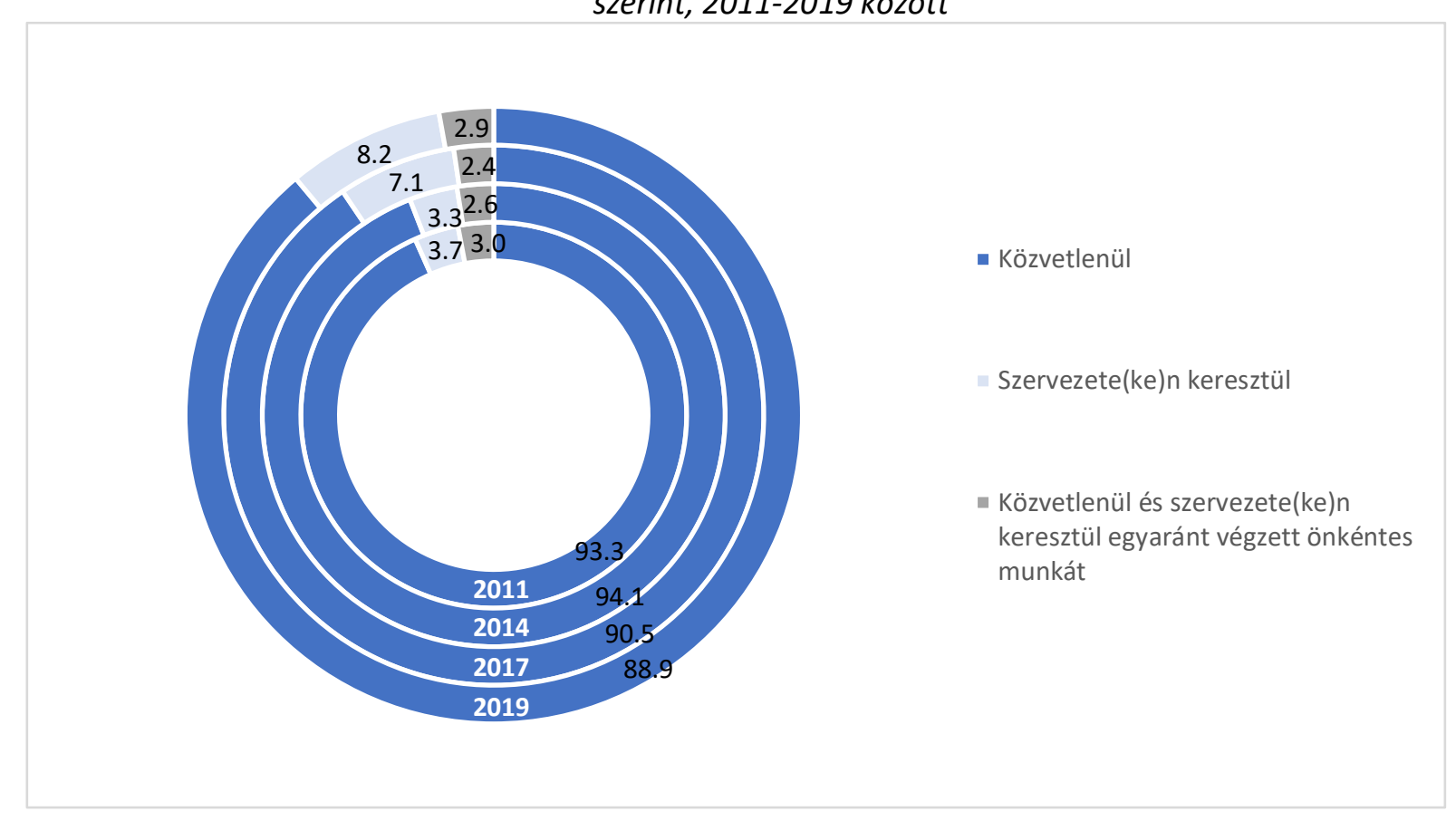

Forrás: KSH, Munkaerő-felmérés, Önkéntes munka c. kiegészítő felvételek 2011-2019.

A szervezeten keresztül ingyenesen segítők száma 2011 és 2019 között két és félszeresére (196 ezer före) bővült, ugrásszerű növekedés 2014 és 2017 között következett be, amikor is a formális önkéntesség súlya azáltal nőtt, hogy az önkéntesség egyre szélesebb körben jelent meg az intézményekben és valószínúleg nem függetlenül az érettségi feltételéül szabott közösségi szolgálat bevezetésétől.

A társadalom múködését az önkéntesség mindkét (informális és formális) formájában önzetlenül, ingyen végzett munkájukkal segítők létszáma a 2010-es évek folyamán 63-68 ezer fős szinten, gyakorlatilag stagnált.

A Munkaerő-felmérés eredményei is igazolják azt a külföldi és hazai szakirodalomban szereplő, kutatásokkal alátámasztott feltevést, miszerint az emberek társadalmi helyzete, demográfiai jellemzői és az önkéntesség között szoros kapcsolat van. Az is igazolást nyert, hogy a formális önkéntesség erősebben függ attól, hogy a magánszemély milyen demográfiai csoporthoz tartozik, milyen társadalmi státuszú. Mivel a hazai önkéntességi struktúra a 
formális - informális dimenzió mentén messze nem kiegyensúlyozott, így az önkéntes munkát végzőket nem célszerű homogén csoportként vizsgálni. Az informális önkéntesek dominanciája ugyanis olyan mértékű, hogy a jellemzők bemutatásakor a formális önkéntesek sajátosságai többnyire rejtve maradnának. A következőkben ezekre a különbségekre is igyekszünk rávilágítani.

\section{AZ ÖNKÉNTESSÉG MINDKÉT - FORMÁLIS ÉS INFORMÁLIS - FORMÁJÁBAN TÖBB NŐ TEVÉKENYKEDETT}

Az önkéntes munka valamennyi formáját figyelembe véve megállapítható, hogy a 15-74 éves népesség körében a nők nagyobb számban és arányban kapcsolódtak be az ellenszolgáltatás nélküli tevékenységekbe, mint a férfiak (3. ábra).

3. ábra A formális és informális önkéntességi ráta³ alakulása nemek szerint, 2011-2019 között

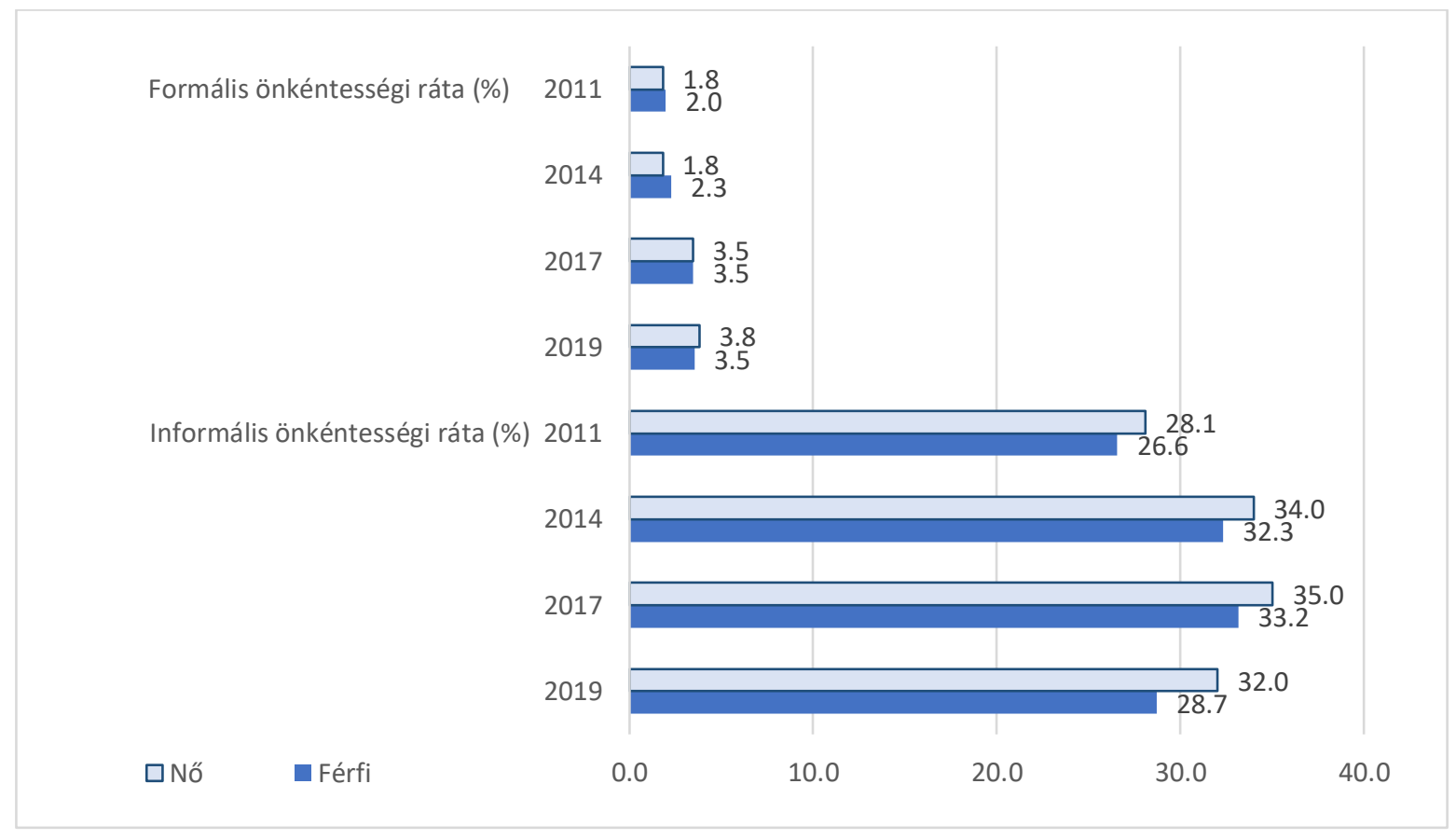

Forrás: KSH, Munkaerő-felmérés, Önkéntes munka c. kiegészítő felvételek 2011-2019.

A nők 29-38 százaléka (1 millió 148 ezer és 1 millió 417 ezer fő közötti létszámban) segített munkájával, míg a férfiak 28-36\%-a (1 millió 5 ezer és 1 millió 252 ezer fő között).

\footnotetext{
${ }^{3}$ Mind a formális, mind pedig az informális önkéntességi ráta számlálójában szerepelnek azok a személyek, akik az önkéntesség mindkét formájában végeztek önkéntes tevékenységet a felvételt megelőző 12 hónap során 2014: 65244 fő (ebből: 35166 férfi és 30078 nő); 2017: 63484 fő (ebből: 303019 férfi és 33165 nő); 2019: 68100 fő (ebből: 35141 férfi és 32959 nő);
} 
Szervezeten keresztül, szervezet bekapcsolásával az évtized első felében még több férfi végzett önkéntes munkát, mint nő. 2014-ben 81 ezer férfi segített ilyen módon, szemben a 70 ezer nővel (beleszámítva még azt a 35 ezer férfit, illetve 30 ezer nőt, akik ilyen tevékenységük mellett közvetlenül is támogatták a rászorulókat vagy valamiféle ügyet). 2017-ben a korábban említett ugrásszerű növekedés kísérőjelenségeként a női formális önkéntesek száma már meghaladta a férfiakét (131 ezer versus 122 ezer), és 2019-ben tovább emelkedett (142 ezerre) a női formális önkéntesek száma, miközben a férfiak körében gyakorlatilag stagnálás volt tapasztalható (4. ábra).

4. ábra A nők aránya a formális és informális önkénteseken belül, 2011-2019 között

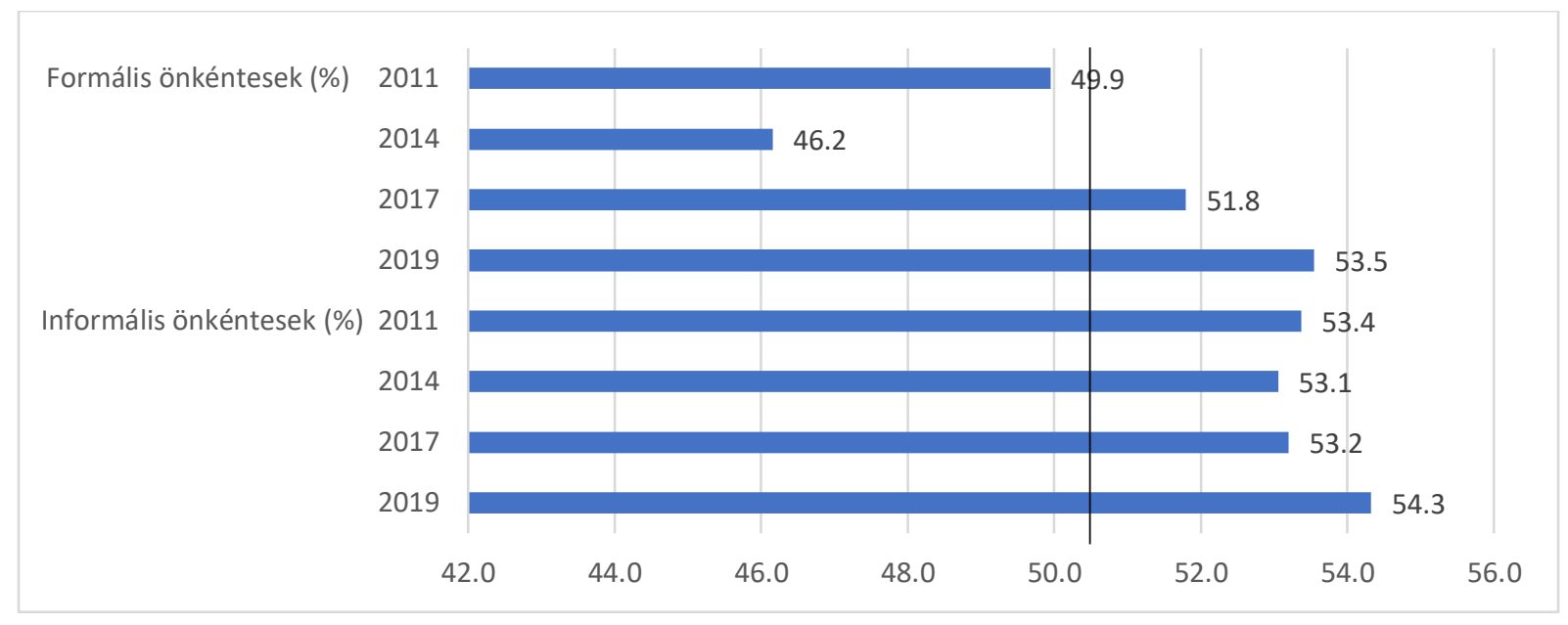

Forrás: KSH, Munkaerő-felmérés, Önkéntes munka c. kiegészítő felvételek 2011-2019.

\section{KISSÉ ELÖREGEDŐVÉ VÁLT AZ ÖNKÉNTES MUNKÁT VÉGZŐK KORSTRUKTÚRÁJA}

A magyarországi önkéntes munkát végzőket kissé elöregedő korstruktúra jellemezte, jóllehet az elmúlt évek változásai a korcsoportonkénti kiegyenlítődés irányába hatottak (5. ábra). Míg a 2010-es évek elején az önkéntességi arány a 15-19 évesek körében volt a legalacsonyabb (18,9 százalék) és a 60-64 éves korcsoportig fokozatosan nőtt, ott elérve a csúcsát (37,6 százalék), addig a 2019-es felvétel adatai szerint az önkéntes munka vállalása - a 15-19 éves korcsoport speciális helyzetétől eltekintve - legmagasabb arányban (37,9 százalék) az 50-54 éveseket jellemezte.

A 15-19 éves korcsoportban megfigyelhető átlag feletti és egyben legmagasabb (38,6 százalék) arány elsősorban az iskolai közösségi szolgálat kiterjesztésének volt a 
következménye. Jóllehet a Nemzeti Önkéntes Stratégia ${ }^{4}$ 2012-2020 kimondja, hogy a közösségi szolgálatot el kell különíteni az önkéntes tevékenységen belül, ugyanis az ilyen jellegű „vállalások” leginkább „csak” bevezető lépésnek tekinthetők a valódi önkéntes tevékenységek irányába, elemzésünkben ezt a csoportot nem zárjuk ki a megfigyelés köréből, inkább csak utalásokat teszünk rá.

\section{5. ábra Az önkéntességi ráta alakulása korcsoportok szerint, 2011-2019 között}

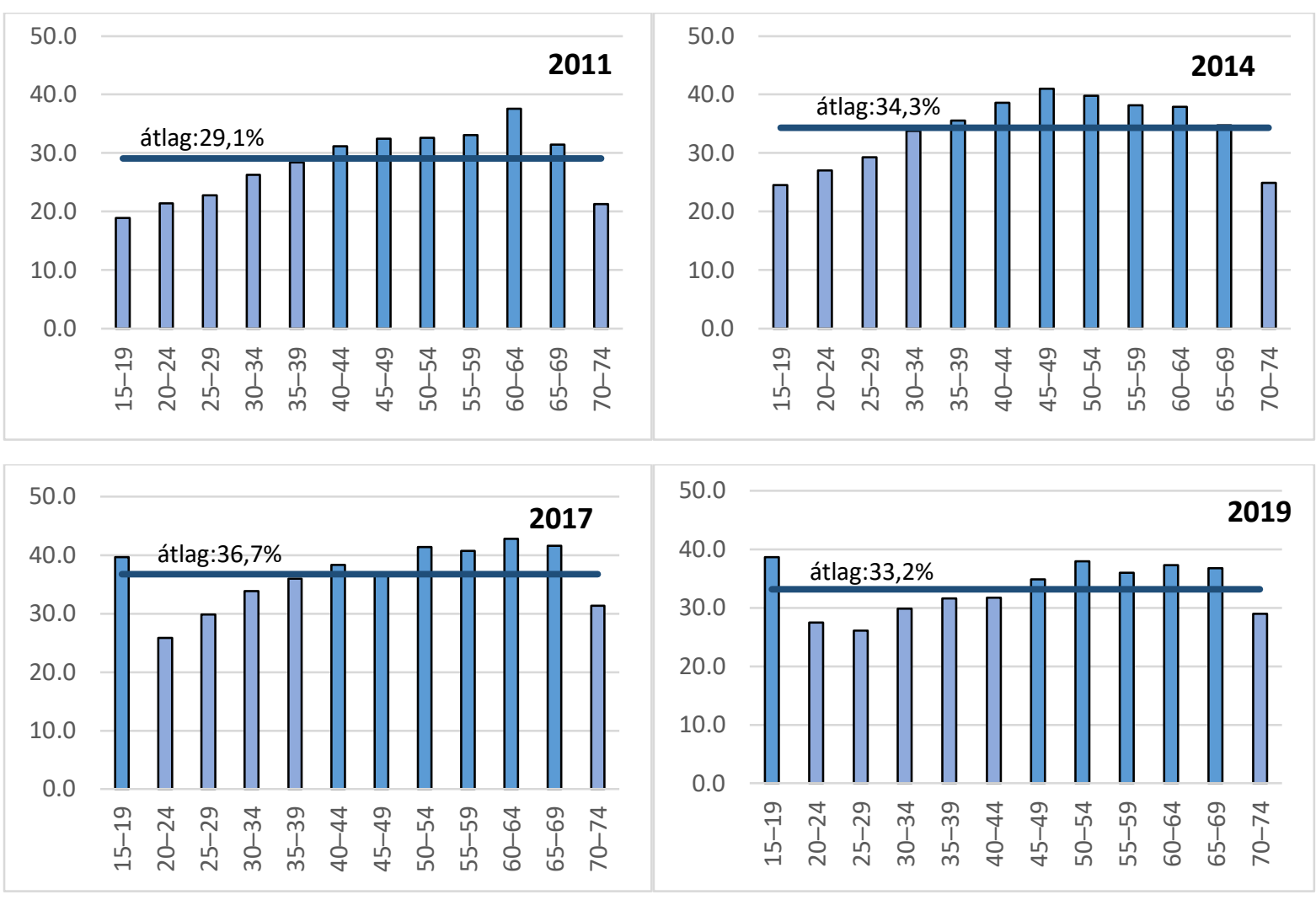

Forrás: KSH, Munkaerő-felmérés, Önkéntes munka c. kiegészítő felvételek 2011-2019.

A 20-39 év közötti korcsoportok esetében az önkéntesség az átlagosnál többnyire alacsonyabb volt, 21,5 és 36,0 százalék közötti, de az a tendencia is jól tetten érhető, ami szerint az életkor mentén a segíteni akarás, a társadalmi szerepvállalás, elköteleződés növekedett. A fiatalok esetében, - ahogy azt a felvétel eredményei mellett más nemzetközi kutatások eredményei is alátámasztják - a „klasszikus” motivációkat egyre inkább a szakmai tapasztalatszerző, ún. új típusú önkéntes motivációk váltották fel: például a munkatapasztalat-

\footnotetext{
${ }^{4}$ A nemzeti köznevelésről szóló 2011. évi CXC. törvény a 2012/2013-as tanévtől kezdődően felmenő rendszerben vezette be a nemzeti köznevelés rendszerébe az iskolai közösségi szolgálatot. A közösségi szolgálat szociális, környezetvédelmi, a tanuló helyi közösségének javát szolgáló, szervezett keretek között folytatott, anyagi érdektől független, egyéni vagy csoportos tevékenység.
} 
szerzés, a készségfejlesztés, a kapcsolatépítés stb. Ebből következően joggal feltételezhető, hogy az érettségi feltételeként kötelezővé tett középiskolai közösségi szolgálat mellett az ilyen jellegú indíttatások eredményezték, hogy az elmúlt években a fiatalok körében, különösen a 20-29 éves korosztályban az önkéntesség szélesebb körben jelent meg.

A 40 év alattiak további korcsoportjaiban az önkéntesség átlagosnál alacsonyabb arányát a szakmai (álláskeresés, elhelyezkedés, karrierépítés) és magánéleti (párkapcsolat, gyermekvállalás) tervek megvalósítása érdekében tett lépések is magyarázhatják. Az egzisztenciateremtés, a családalapítás, a gyermekvállalás, a gyermek születésével, gondozásával járó plusz kötelességek ugyanis olyan élethelyzetek, amelyekben a jövedelmet biztosító munka prioritást élvezhet az önkéntes munkával szemben, amikor a fiatalok sokkal inkább a saját közös életükre koncentrálnak, mint a közösség érdekeire. Ugyanakkor a gyermekek száma és kora jelentős hatással lehet az önkéntes munkavégzésre.

Az önkéntesek aránya a 40-69 évesek ötéves korcsoportjaiban átlag fölötti volt: az ilyen korúak közül 100 főből átlagosan 37 kapcsolódott be valamiféle önkéntes tevékenységbe 2011 és 2019 között. Az 50-69 évesek körében az önkéntesek aránya magas szinten állandósult. A korosztály tagjai nagymértékben kapcsolódtak be - felnőtt korú gyermekeik, illetve szüleik, rokonaik révén - a gyermekfelügyelettel, az idős- és beteggondozással kapcsolatos szociális tevékenységekbe. A 65-69 éves korcsoport magas önkéntességi aktivitása pedig azért is jelzésértékű, mert azt mutatja, hogy a nyugdíjba vonulást követően az idősödő népesség nem válik a munka világában hirtelen passzívvá és szakad ki a társadalmi tevékenységekből, hanem önkéntes tevékenysége révén segít másokon vagy szolgál valamilyen társadalmi ügyet.

\section{KIUGRÓAN MAGAS VOLT A 15-24 ÉVESEK SZERVEZETEKEN KERESZTÜL VÉGZETT ÖNKÉNTESSÉGE}

A szervezeten keresztül, illetve annak javára önkéntes munkát végzők aránya az önkénteseken belül - mint már említettük - nagyon alacsony volt, és az életkor növekedésével ez a részvételi arány csökkenő tendenciát mutatott (6. ábra).

A 15-24 évesek esetében az évtized közepétől megfigyelhető kiugróan magas részvételi arányt elsősorban a már említett, az érettségihez szükséges közösségi szolgálat igazolása érdekében végzett tevékenység magyarázza véleményünk szerint. A hagyományos önkéntesség mellett ugyanakkor főként ezt a korcsoportot jellemezte az új típusú önkéntesség 
irányába történő elmozdulás, ahol a szaktudás, a gyakorlati tapasztalat megszerzése, a kapcsolati háló bővítése és hasonló, a tudásalapú társadalomra jellemző társadalmi értékek állnak a középpontban.

6. ábra A szervezeten keresztül, szervezetek javára önkéntes tevékenységet végzők aránya az önkénteseken belül korcsoportok szerint 2011-2019 között

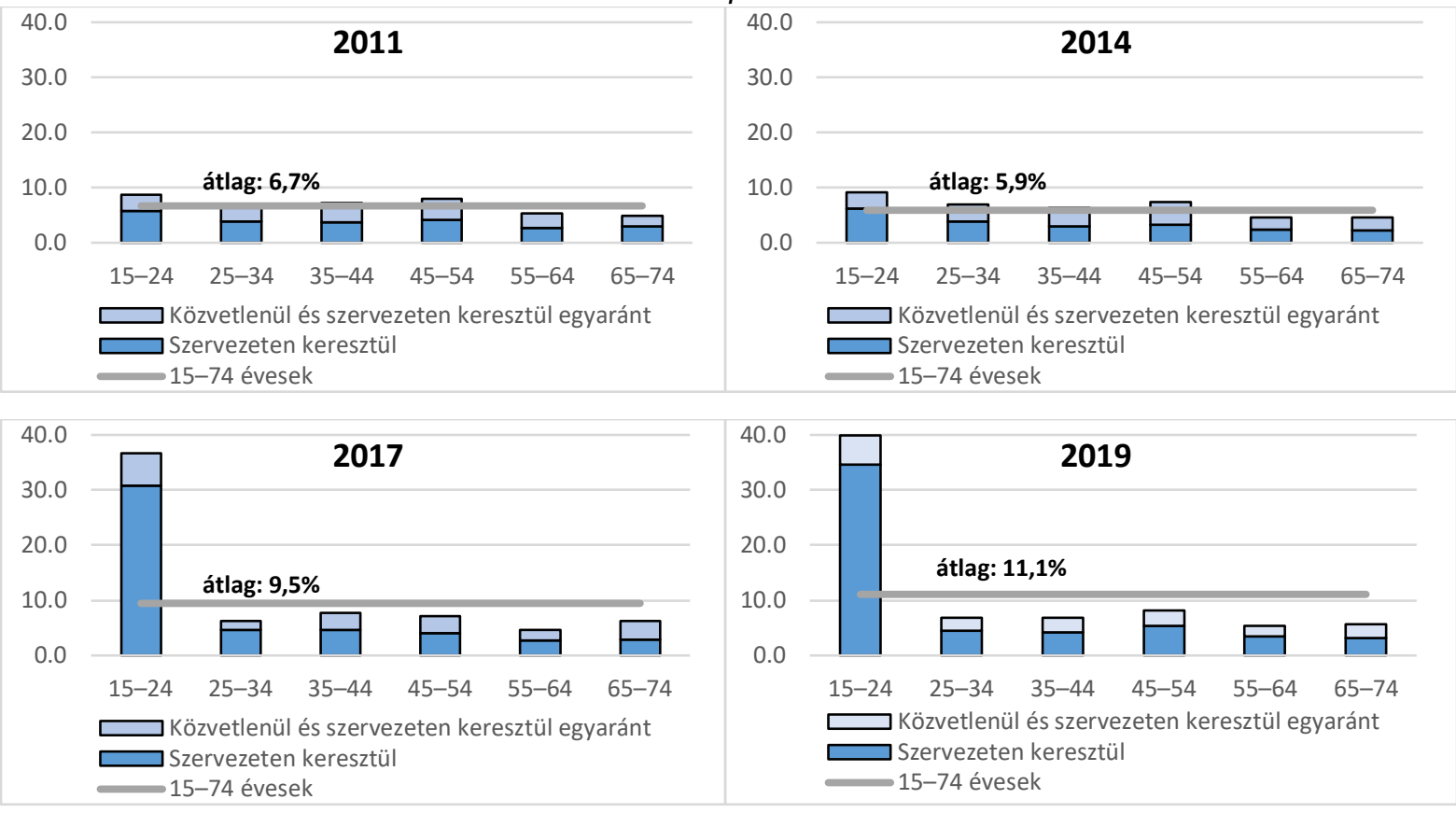

Forrás: KSH, Munkaerő-felmérés, Önkéntes munka c. kiegészítő felvételek 2011-2019.

A 45-54 évesek körében a formális önkéntesség relatív magas volt, melyet többek között az is magyarázott, hogy a megszerzett tudás, illetve kellő munkatapasztalat birtokában a korcsoporthoz tartozók több közéleti szerepet vállaltak, a társadalmi szervezetekben aktívabbak, és a társadalmi felelősségvállalásuk is magasabb volt.

\section{LEGMAGASABB ARÁNYBAN A FELSŐFOKÚ VÉGZETTSÉGŰEK VÉGEZTEK ÖNKÉNTES} MUNKÁT

Az iskolázottság a jótékonysági magatartás fontos meghatározója, az önkéntes segítők aránya a legmagasabb iskolai végzettségi szinttel növekedett, és a diplomások körében volt a legmagasabb. Míg a legfeljebb alapfokú végzettségúek 23,7 százaléka végzett önkéntes tevékenységet 2011-ben és 30,5 százaléka 2019-ben, addig a középfokúaknak 29,7, illetve 33,3 százaléka, a diplomásoknak pedig 31,6, illetve 35,4 százaléka. 
Az iskolázottsági struktúra tekintetében is a kiegyenlítődés irányában történtek az elmozdulások. 2011-ben az alap-, illetve a felsőfokú végzettségűek önkéntességi arányában 7,9 százalékpontos különbség mutatkozott, a legutóbbi felvételben azonban ez a különbség 4,9 százalékpontra csökkent (7. ábra).

7. ábra Az önkéntességi ráta alakulása legmagasabb iskolai végzettség szerint, 2011-2019 között

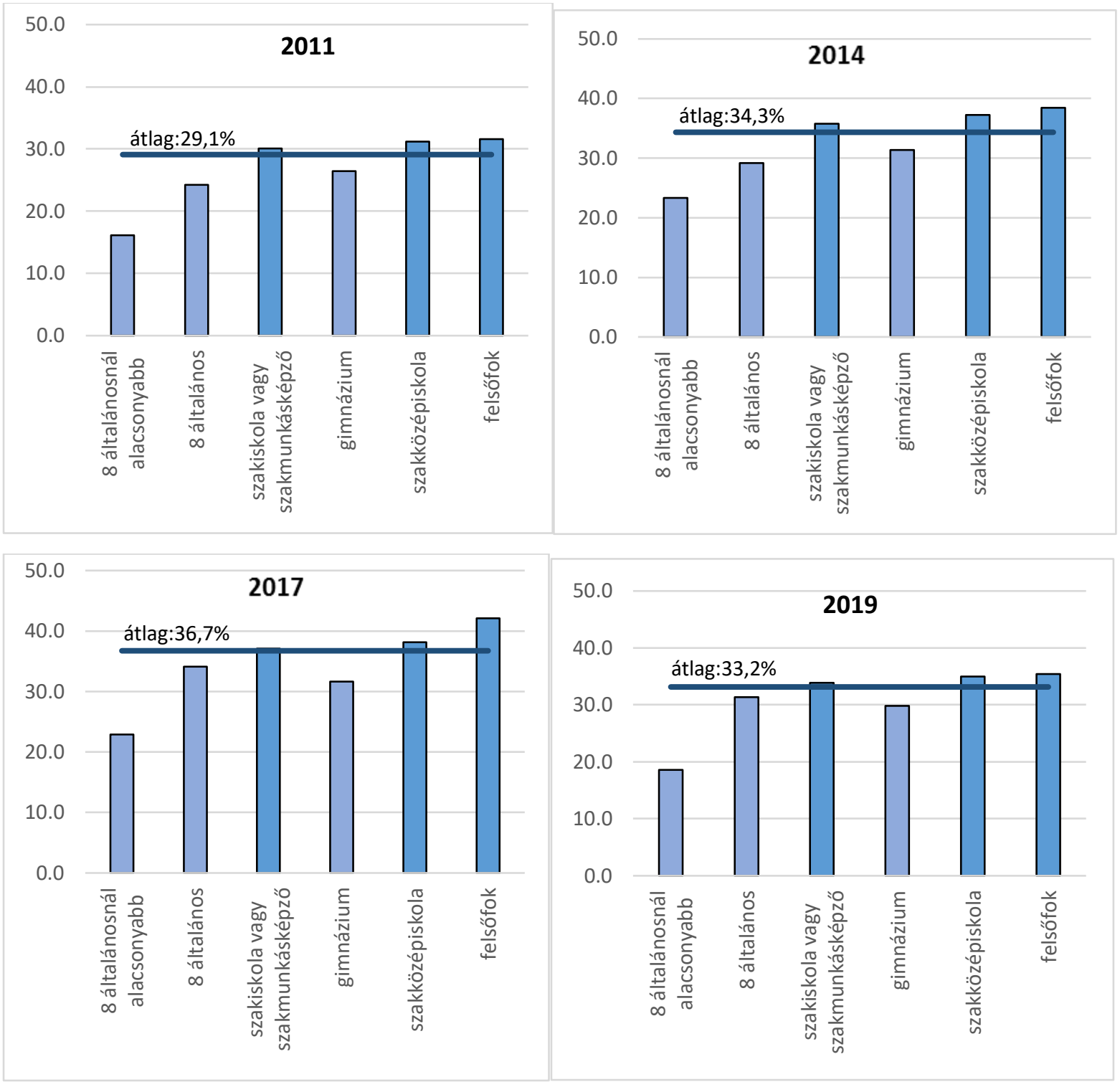

Forrás: KSH, Munkaerő-felmérés, Önkéntes munka c. kiegészítő felvételek 2011-2019.

A szakmai végzettség továbbra is differenciáló tényezőnek tekinthető. A középfokú végzettséggel rendelkezők körében mind az érettségivel nem rendelkező, mind pedig az érettségizett szakmai végzettségűek az átlagosnál magasabb, a felsőfokúakéhoz nagyon közelálló aktivitást mutattak az önkéntesség tekintetében, miközben a gimnáziumi 
végzettségűek önkéntessége - hasonlóan a legfeljebb alapfokú végzettségűek arányaihoz átlag alatti volt (26,4 és 31,7 százalék közötti értékekkel).

Az átlagot jelentősen meghaladó mértékben nyújtottak támogatást 2011 és 2019 között az oktatás (időrendben: 45,7, 36,8, 51,2 és 43,9 százalék), illetve az egészségügyi és szociális gondoskodás területen (időrendben: 38,3, 34,4, 39,1 és 37,5 százalék) szakmai végzettséget szerzettek, amit feltételezhetően a felmerülő igények természete, illetve „kényszerítő ereje” határozott meg nagyban.

Miután a közvetlenül (informálisan) önkéntes munkát végzők alkotják az önkéntesek meghatározó sokaságát, így a legmagasabb iskolai végzettség szerinti önkéntességi arányukról ugyanaz mondható el, mint a teljes önkéntes sokaságról, vagyis, hogy az egyre magasabb iskolai végzettséggel rendelkezők egyre nagyobb arányban adományoztak időt és energiát mások, vagy a társadalom javára. 2011-ben az alapfokú végzettségúeknek 23,1, a középfokúaknak 28,8, a felsőfokúaknak pedig 29,4 százaléka végzett közvetlenül önkéntes munkát. 2019-re ezek az arányok nőttek; 1,3, 2,9, illetve 4,2 százalékponttal.

Szervezeten keresztül vagy szervezet javára 2011-ben az alapfokú végzettségúeknek 1,1, a középfokúaknak 1,7, a felsőfokúaknak pedig 3,8 százaléka végzett ingyenesen munkát. Körükben is nőttek az arányok 2019-re; 5,9, 0,7, illetve 0,2 százalékponttal.

$A z$ informális, illetve formális önkéntesség iskolai végzettség szerinti struktúrája az évtized folyamán jelentősen átalakult. 2011-ben az informális önkéntesek 23 százaléka volt alapfokú végzettségü, miközben a formális önkénteseknek csak 15,4 százaléka. A társadalom általános iskolázottsági szintjének növekedésével a nagy számosságú informális önkéntesek körében is nőtt az iskolázottság, melynek következtében 2019-re a legfeljebb alapfokú végzettségűek aránya 17 százalékra csökkent (8. ábra).

Mindeközben a formális önkéntességen belül az alapfokú végzettségúek aránya jelentősen (25,1 százalékponttal), 40,3 százalékra nőtt. Valószínűsíthető, hogy túlnyomó többségében azok a középfokú intézményben tanulók duzzasztották fel ezt az arányt, és tartoztak a legfeljebb alapfokú végzettségűek közé, akik az érettségi feltételéül szabott közösségi szolgálatban vettek részt.

A felsőfokú végzettségúek mellett a gimnáziumi érettségivel rendelkezők - zömében nők formális önkéntes tevékenysége volt átlagot meghaladó 2019-ben. Ennek oka lehetett, hogy a nők segítő attitűdje a családi feladataik mellett, azt kiegészítve olyan formális önkéntességi 
tevékenységekben is releváns, mint az óvoda, iskola segítése, rendezvényszervezés, vallással kapcsolatos, egyházi szervezetnél végzett tevékenység stb.

8. ábra Az önkéntességi ráta alakulása az önkéntesség formája és legmagasabb iskolai végzettség szerint, 2011 és 2019

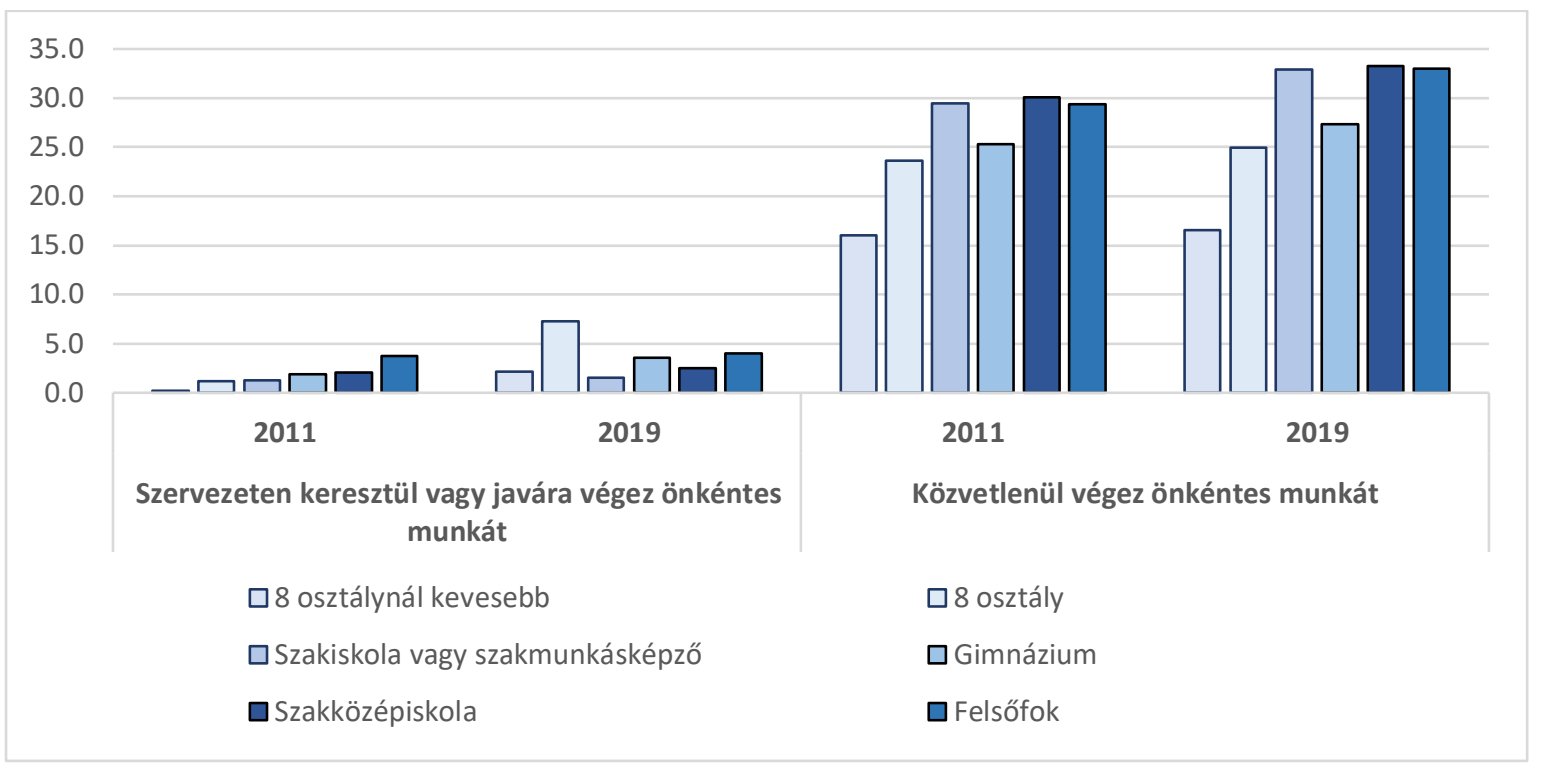

Forrás: KSH, Munkaerő-felmérés, Önkéntes munka c. kiegészítő felvételek 2011-2019.

\section{ÁTLAG FELETTI SEGÍTSÉGNYÚJTÁS JELLEMEZTE A KISTELEPÜLÉSEKET}

A hazai önkéntességre általában igaz, hogy a települési lejtő mentén nő az önkéntesek aránya. A 2010-es években végrehajtott felvételek arról tanúskodnak, hogy a Budapesten élők jóval az átlag alatt segítettek másokat önkéntes tevékenységükkel, miközben a többi városban a budapestit jelentősen, az országos átlagot kismértékben meghaladó volt az önkéntesség. A legmagasabb, átlag feletti segítségnyújtás a községeket, kis lélekszámú településeket jellemezte (9. ábra).

Ennek fő magyarázó tényezője, hogy a kisebb települések, közösségek szükségletei jobban átláthatók, így az azok kielégítésére irányuló törekvések is mind egyéni, mind pedig szervezeti kezdeményezés keretében könnyebben megvalósíthatók. A nyilvánosság motiváló hatása is az egymást ismerők esetében nagyobb, vagyis a kistelepüléseken élők körében érvényesül a leginkább az ilyen jellegű motiváció.

A gazdasági aktivitási adatok azt mutatták, hogy a fizetett munkával rendelkezők (foglalkoztatottak) ingyenes, önkéntes munkát is magasabb arányban végeztek. Ezért azt várnánk, hogy a munkaerő-piaci szempontból kedvező helyzetű területeken magasabb az 
önkéntesek aránya. Ezzel szemben azt találtuk, hogy az önkéntesen, ellenszolgáltatás nélkül, az átlagosnál magasabb arányban olyan megyék lakói tevékenykedtek, amelyeket közepes vagy alacsony foglalkoztatottság jellemzett.

9. ábra Az önkéntességi arány alakulása a település típusa szerint, 2011-2019 között

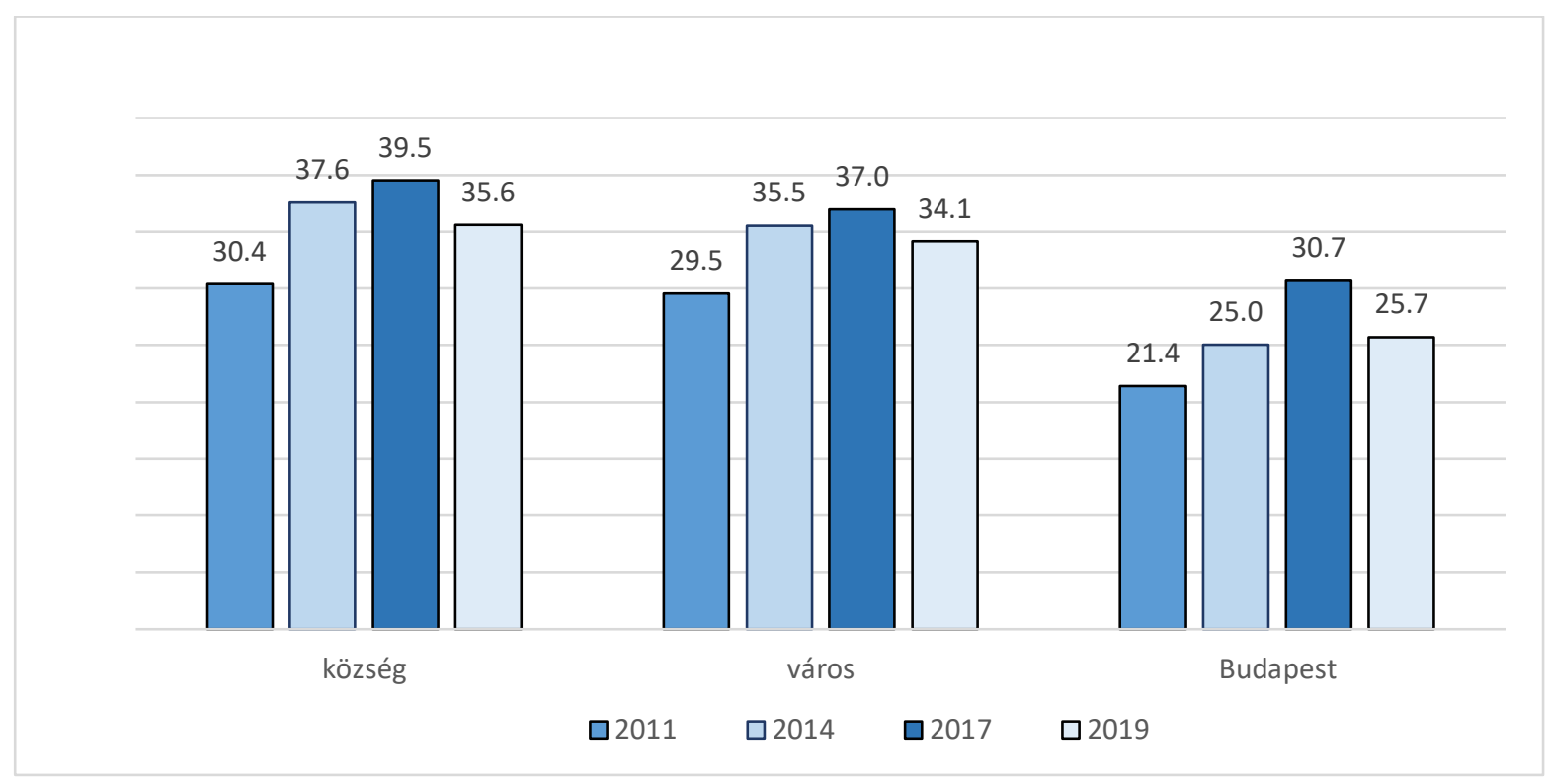

Forrás: KSH, Munkaerő-felmérés, Önkéntes munka c. kiegészítő felvételek 2011-2019.

Ezeknek a megyéknek lényeges sajátossága, hogy aprófalvas, kis lélekszámú települések tagolják, ahol a lakosok egymáshoz való viszonya, összefogási képessége magas önkéntességet eredményezett.

2019-ben a legmagasabb önkéntességi arány Jász-Nagykun-Szolnok megyét jellemezte, ahol a 15-74 évesek közel kétharmada (62,1 százalék) végzett önkéntes munkát, de említésre méltó volt Nógrád (46,3 százalék) és Heves (42,1 százalék) megye is, ahol a lakosság majdnem fele kapcsolódott be önkéntes tevékenységekbe, ami az országos 33,2 százalékos átlagot jelentősen meghaladta.

\section{A HÁZASSÁGBAN ÉLŐKRE JELLEMZŐBB VOLT AZ ÖNKÉNTES MUNKAVÉGZÉS}

Önként vállalt, ellenszolgáltatás nélküli tevékenységet a házasságban élők az átlagosnál jóval magasabb arányban végeztek, 2011-ben 33,3 százalékuk, 2019-ben 36,2 százalékuk segített másokon, vagy szolgált valamilyen közösségi, társadalmi ügyet a felvételt megelőző 12 hónapban (10. ábra). Ennek részben az lehet a magyarázata, hogy az együttélés, az áldozatvállalás normáinak a kényszerítő ereje a családokban nagyobb, továbbá a személyes 
példamutatás igénye és lehetősége is erősebb. A házasok ugyanis gyakrabban élnek idős, beteg, gondozásra, ápolásra szoruló hozzátartozójuktól külön háztartásban, és segítenek nekik (ami az alkalmazott módszertannak megfelelően önkéntes tevékenységnek számít), gyakrabban nevelnek gyermekeket, akik közösségei (egyre) nagyobb arányban igénylik a szülői támogatást, az ingyenes segítséget.

10. ábra Az önkéntesek aránya családi jellemzők szerint, 2011 és 2019

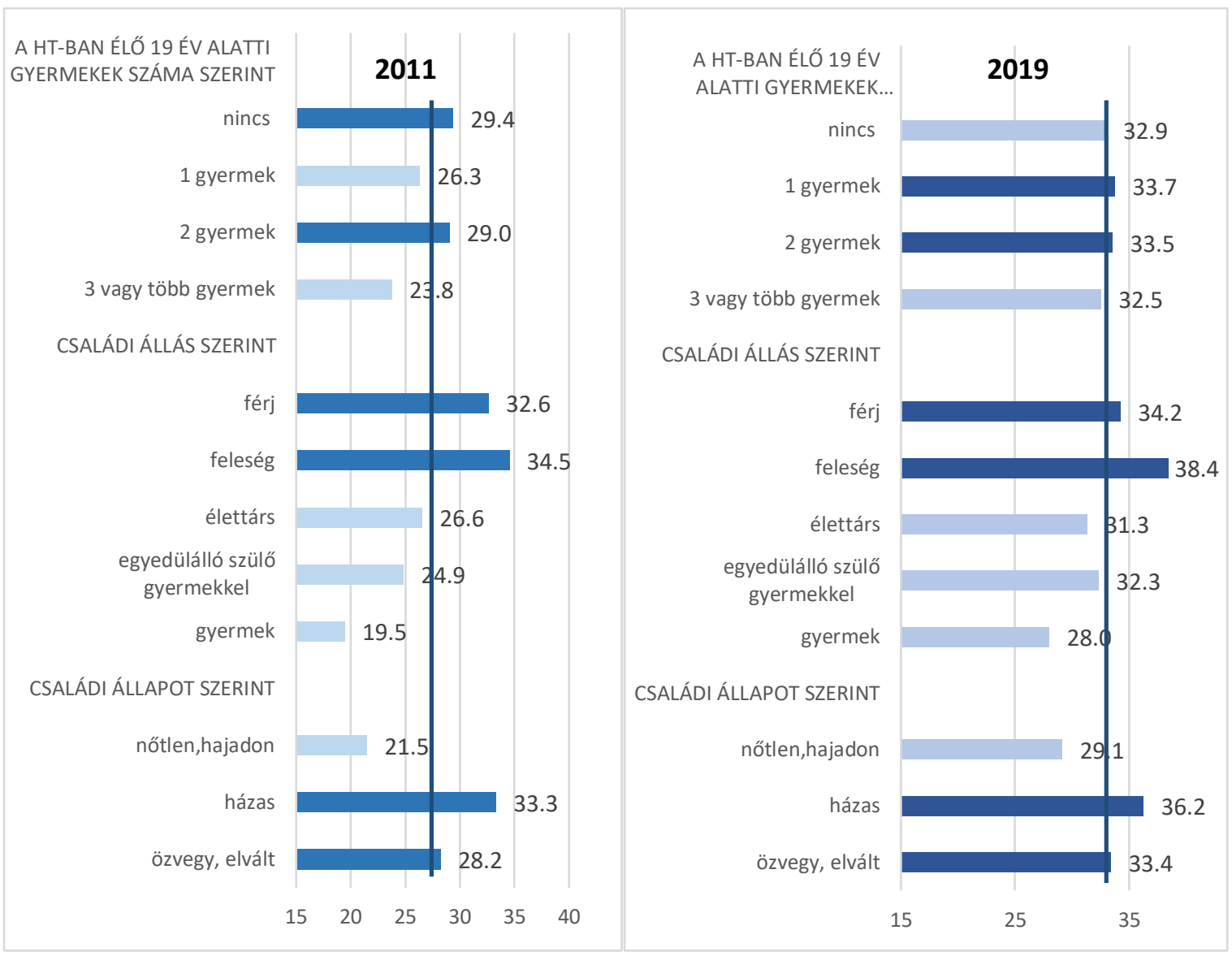

Forrás: KSH, Munkaerő-felmérés, Önkéntes munka c. kiegészítő felvételek 2011; 2019.

\section{AZ ÖNKÉNTESEK LEGINKÁBB HÁZI- ÉS HÁZKÖRÜLI MUNKÁKAT VÉGEZTEK}

A négy felvétel adatai szerint a házi- és házkörüli munka, az ügyintézés és vásárlás, a gyermekfelügyelet, gyermekgondozás, illetve a betegápolás, idősgondozás volt az önkéntesség leggyakoribb megjelenési formája. Az önkéntesek által - rendszeresen vagy alkalmanként - végzett összes tevékenység háromnegyedét is ezek a tevékenységek alkották (11. ábra). Egy önkéntes több tevékenységi területen is nyújtott segítséget, s ennek eredményeként 4-4,5 millió tevékenység került jelölésre. 
11. ábra Az önkéntes munkát végzők száma tevékenységi területenként, 2011-2019 között

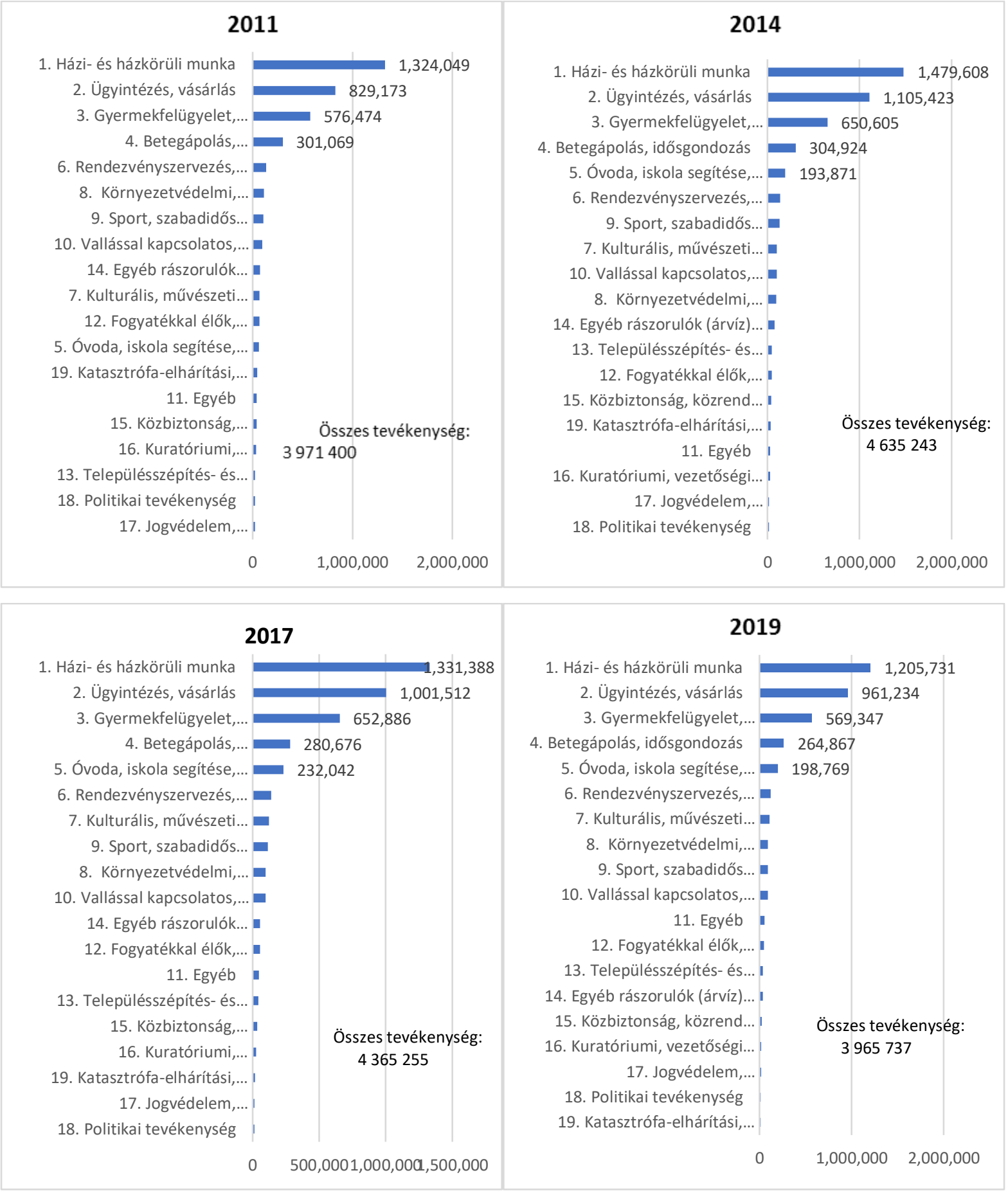

Forrás: KSH, Munkaerő-felmérés, Önkéntes munka c. kiegészítő felvételek 2011-2019.

Az önkéntes munka rendszerességét illetően, a 2019-es adatok alapján azt tapasztaltuk, hogy elsősorban a formális önkéntes tevékenységek tartoztak ebbe a körbe, olyanok, mint a közbiztonság, közrend védelme, a polgárőrség vagy a kuratóriumi tagság, illetve adminisztratív munkák, a jogvédelemmel kapcsolatos tevékenységek. 
Ugyanakkor ki kell emelni, hogy a négy fő - mintegy 3 millió esetet jelentő - önkéntes tevékenység több, mint egynegyede rendszeres segítség formájában valósult meg (12. ábra).

12. ábra Az önkéntes tevékenységek területei és rendszeressége, 2019 (\%)

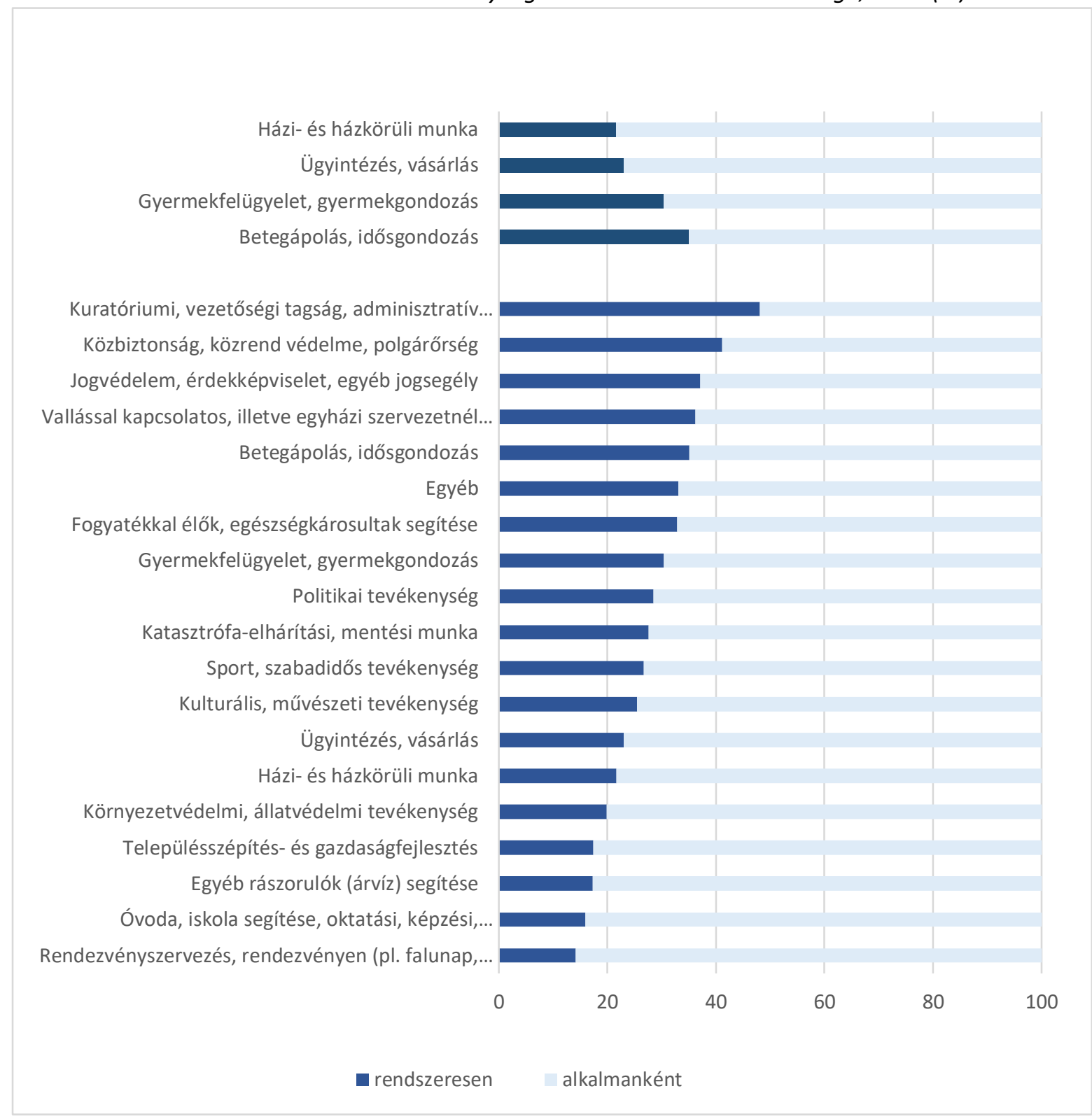

Forrás: KSH, Munkaerő-felmérés, Önkéntes munka c. kiegészítő felvételek 2019.

\section{A KÖZVETLENÜL VÉGZETT (INFORMÁLIS) ÖNKÉNTES TEVÉKENYSÉGEK KEDVEZMÉNYEZETTJEINEK FELE A ROKONI KÖRBE TARTOZOTT}

Az önkéntes tevékenység kedvezményezettjei sokfélék lehetnek, és közvetlen vagy közvetett módon részesülhetnek a tevékenységek „eredményeiből”. A négy felvétel adatai azt mutatják, hogy a közvetlen segítségnyújtással kedvezményezettek száma ugyan nagyon eltérően alakult 
(2011-ben volt a legalacsonyabb, 3 millió 238 ezer és 2017-ben a legmagasabb 4 millió 117 ezer), a struktúra azonban az évtized folyamán szinte nem változott. 2019-ben a 2 millió 189 ezer közvetlen önkéntes tevékenységének 3 millió 374 ezer kedvezményezettje volt, akik többsége a háztartáson kívül élő családi, rokoni, (50,8 százalék), illetve a baráti (21,5 százalék) körhöz tartozott (13.ábra).

13. ábra A közvetlen önkéntes tevékenységek kedvezményezettjeinek száma és aránya, 2019

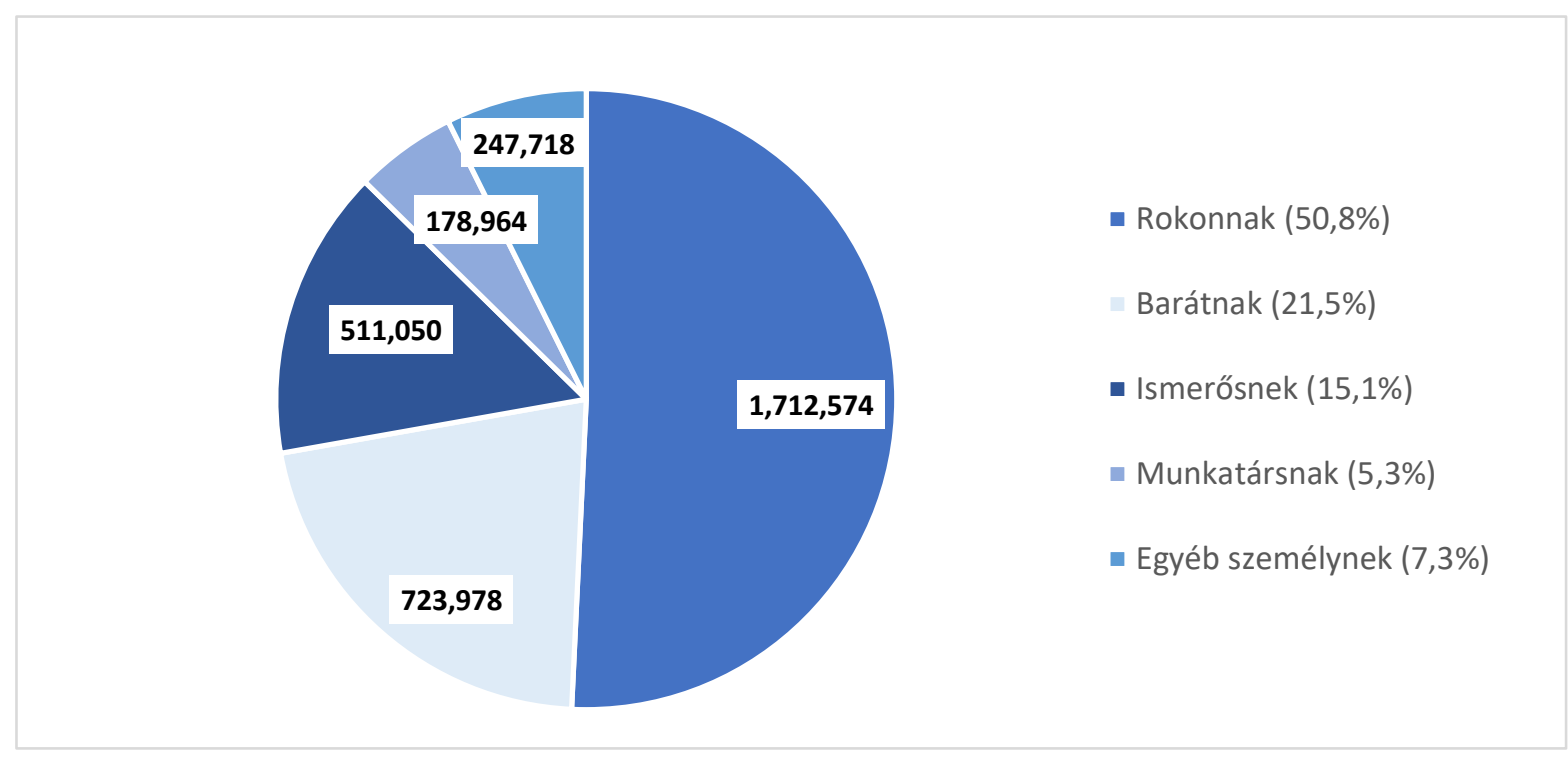

Forrás: KSH, Munkaerő-felmérés, Önkéntes munka c. kiegészítő felvételek 2019.

$A z$, hogy ilyen magas arányban voltak azok, akik rokonokat, barátokat támogattak ingyenes munkájukkal, több dologra is ráirányítja a figyelmet. Egyrészt a hazai önkéntesség azon jellemzőjére, hogy olyan területeken és tevékenységekkel van jelen a társadalomban, ahol és amelyeket valójában az államnak, vagy valamiféle közösségeknek kellene biztosítani. Hiánypótló jellegével, illetve ingyenességével olyan valós igényeket elégít ki, amelyekre az államnak, a közösségeknek komoly anyagi és humán erőforrásokat kellene áldozni. Továbbá azt is sugallja, hogy az önkéntesség részben tudatos értékek mentén valósul meg. Feltételezhető ugyanis, hogy akik ily módon segítenek, azok a családi, rokoni, baráti körön kívül is hasonlóan viselkednek.

A közvetlen (informális) önkéntes tevékenységek 27,7 százalékának kedvezményezettjei olyan személyek voltak, akik nem tartoztak a családi, baráti körhöz: 15,1 százalék az ismerősök, 5,3 százalék a munkatársak köréből került ki, további 7,3 százalék pedig egyéb személyek javára valósult meg. Ennek az utóbb említett körnek a javára az önkéntesek többnyire olyan 
tevékenységeket végeztek, mint például óvoda, iskola segítése, oktatási, képzési, tudományos tevékenység vagy kulturális, múvészeti tevékenység stb., amelyek már a formális önkéntesség irányába mutatnak, és ezzel némi magyarázatát adják annak, miért is lehet alulbecsült a felvételben a formális önkéntes tevékenység.

\section{AZ ÖNKÉNTESSÉG LEGFŐBB MOTIVÁCIÓJA A „MÁSOKON SEGITÉS” ÖRÖME VOLT}

A motiváció erősségének feltérképezésére irányuló kérdések a régi típusú, klasszikus, hagyományos önkéntességi magatartásra vonatkozó értékeken túl a modern önkéntesség értékei melletti elköteleződés feltérképezésére is lehetőséget teremtettek. Az eredmények azt mutatják, hogy az önkéntesek legfóbb motivációi az elmúlt közel tíz évben sem a sorrendiséget, sem a nagyságrendet illetően nem igazán változtak.

14. ábra Az önkéntes tevékenységet végzők motivációi 2019

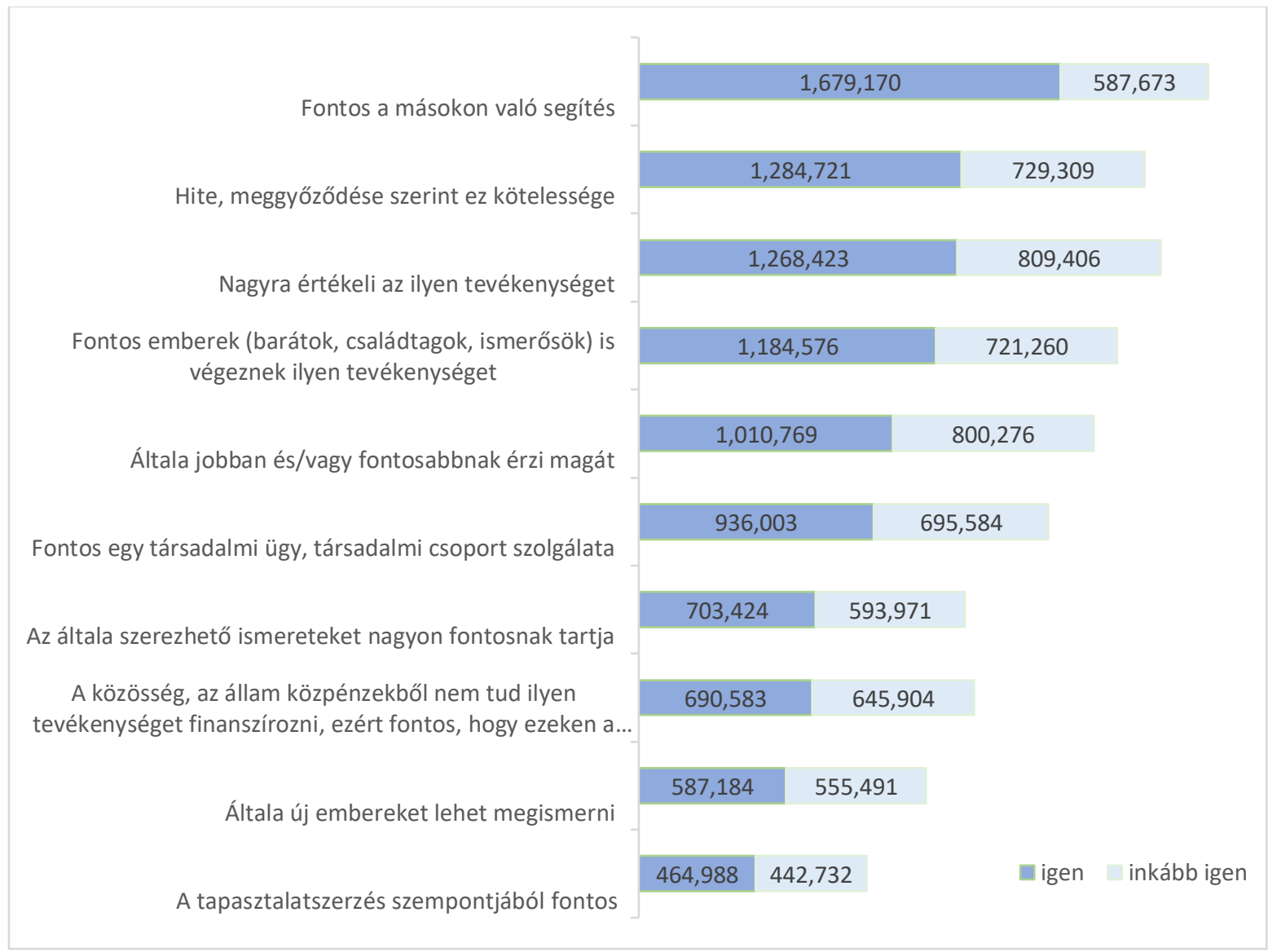

Forrás: KSH, Munkaerő-felmérés, Önkéntes munka c. kiegészítő felvételek 2019.

2019-ben is - a korábbi felvételek eredményeihez hasonlóan - az önkéntes munka leggyakoribb indítéka a „másokon való segítés” öröme volt, amit az önkéntes tevékenységet 
végzők 95 százaléka jelölt meg (14. ábra). E mögött az az általánosnak tekinthető hit, meggyőződés állt a második helyen, ami szerint a rászorulókon segíteni erkölcsi kötelesség (2019: 84,4 százalék). Az önkéntes tevékenység - mint fontos társadalmi érték - melletti elköteleződés a motivációs tényezők között ugyancsak kiemelkedő fontosságúnak bizonyult (2019: 68,4 százalék).

A klasszikusnak számító okok mellett azonban olyanok is egyre inkább előtérbe kerülnek, amelyeket a tudásalapú társadalmakban egyre nagyobb értéket jelentő szaktudás, gyakorlati tapasztalat megszerzése, megőrzése, vagy az élethosszig tartó tanulás indukál. Egyre markánsabban jelennek meg az önkéntesség motiváló tényezőiként olyanok, mint az ismeretek megszerzése (2019: 54,4 százalék), az új emberek megismerése (2019: 47,9 százalék), vagy a tapasztalatszerzés (2019: 38 százalék). Ezek azonban egyúttal azt is jelzik, hogy az önkéntesség átalakulóban van, modernizálódik, igyekszik a kor kihívásainak megfelelni.

\section{AZ ÖNKÉNTESEK ÁLTAL ADOMÁNYOZOTT ÓRÁK SZÁMA FOLYAMATOSAN JELENTŐS VOLT 2011 - 2019 KÖZÖTT}

Az önkéntesek elkötelezettsége, szerepvállalása leginkább az általuk teljesített órákban tükröződik. Mielőtt rátérnénk az adatok részletes ismertetésére, fontos, hogy néhány statisztikai fogalmat tisztázzunk.

- Az önkéntes munkát végzők által teljesített éves óraszám a kikérdezést megelőző 12 hónap során közvetlenül és/vagy szervezeten keresztül önkéntes tevékenységre fordított órák száma összesen. Az önkéntes tevékenységre fordított idő az elmúlt 12 hónapban önkéntes munkával töltött napok, illetve napi perc mennyiségek alapján becsült.

- A közvetlenül (informálisan) önkéntes munkát végzők által teljesített óraszám a kikérdezést megelőző 12 hónap során a közvetlen önkéntes tevékenységre fordított órák száma összesen. Az önkéntes tevékenység-re fordított idő az elmúlt 12 hónapban önkéntes munkával töltött napok, illetve napi perc mennyiségek alapján becsült.

- A szervezeteken keresztül önkéntes munkát végzők által teljesített óraszám a szervezeten keresztül önkéntesként végzett időráfordítás számbavételekor legfeljebb három szervezetnél legfeljebb háromféle tevékenység tételes jelölésére volt lehetőség, illetve a további szervezeteknél ledolgozott időráfordítást együttesen lehetett megadni. A 
statisztikai táblázatokban azonban az egy személy által ledolgozott/teljesített időráfordítások csak abban a nemzetgazdasági ágban, illetve abban a foglalkozási föcsoportban jelennek meg, amelyet a megkérdezett a (leg)fontosabbnak tartott, vagy amelyiknél a legtöbb időt töltötte önkéntes munkával.

- Az éves átlag óraszám az egy önkéntesre jutó óraszám a kikérdezést megelőző 12 hónap során közvetlenül és/vagy szervezeten keresztül önkéntes tevékenységre fordított órák száma alapján kerül kiszámításra.

- Az éves medián ${ }^{5}$ óraszám pedig az az óraszám, amelyre az önkéntes tevékenységet végzők fele azt mondta, hogy ennél kevesebb ilyen jellegű tevékenységet végez, míg a másik fele azt, hogy ennél többet.

2011-ben az önkéntesek által teljesített összes, 346 millió 146 ezer 472 óra 92,6 százaléka közvetlen (informális) segítségnyújtás formájában valósult meg, 3 százaléka szervezeten keresztül, miközben 4,4 százalékát olyan személyek teljesítették, akik mind formális, mind informális önkéntes tevékenységükkel hozzájárultak mások segítéséhez. Ez utóbbi csoportba tartozó személyek éves szinten átlagosan 239,2 óra önkéntes munkát végeztek, szemben a közvetlen (informális) önkéntesek 159,5, illetve a szervezeten keresztül (formális) segítők 129,7 órájával.

A formális önkéntesség irányába történt elmozdulások ellenére az önkéntesek által teljesített órák struktúrája lényegesen nem változott, 2019-ben az informális önkéntesek az összes, 313 millió 620 ezer 459 teljesített óra 90,9 százalékát, a formális önkéntesek a 3,7 százalékát, az önkéntesség minkét formájában segítők pedig az 5,4 százalékát teljesítették. A formális önkéntesek által teljesített meglehetősen alacsony óraszámot nagymértékben meghatározhatta az érettségire készülő diákok 50 órás közösségi szolgálat kötelezettsége.

Azok éves átlagos óraszáma, akik formális és informális módon egyaránt segítettek másokat vagy valamiféle ügyet ingyenes munkájukkal, 247,9 órára nőtt, miközben a csak informális módon segítőké 134,8 órára, a csak formális módon segítőké pedig 59,2 órára csökkent.

Az önkéntes tevékenységre fordított idő vizsgálata nemcsak azt mutatta meg, hogy a nők nagyobb arányban végeztek önkéntes munkát, mint a férfiak, hanem azt is, hogy létszámarányuknál magasabb arányban részesedtek az önkéntesek által teljesített összes

\footnotetext{
${ }^{5}$ A medián a sorba rendezett adatok közül a középső érték, vagyis az az érték, amely a sorba rendezett adatokat két egyenlő részre osztja.
} 
órából. 2011-ben és 2019-ben is az önkéntes órák több, mint 63 százalékát a nők teljesítették. Az egy före jutó éves óraszám azonban 2019-ben mindkét nem esetében alacsonyabb volt a 2011. évi értéknél, a nők által teljesített éves átlagos óraszám jelentősen (38,2 órával) 153,5 órára, a férfiak által teljesített pedig 22,6 órával 106 órára esett vissza (15. ábra).

\section{5. ábra Az önkéntes munkát végzők éves átlagóraszáma nemek szerint}

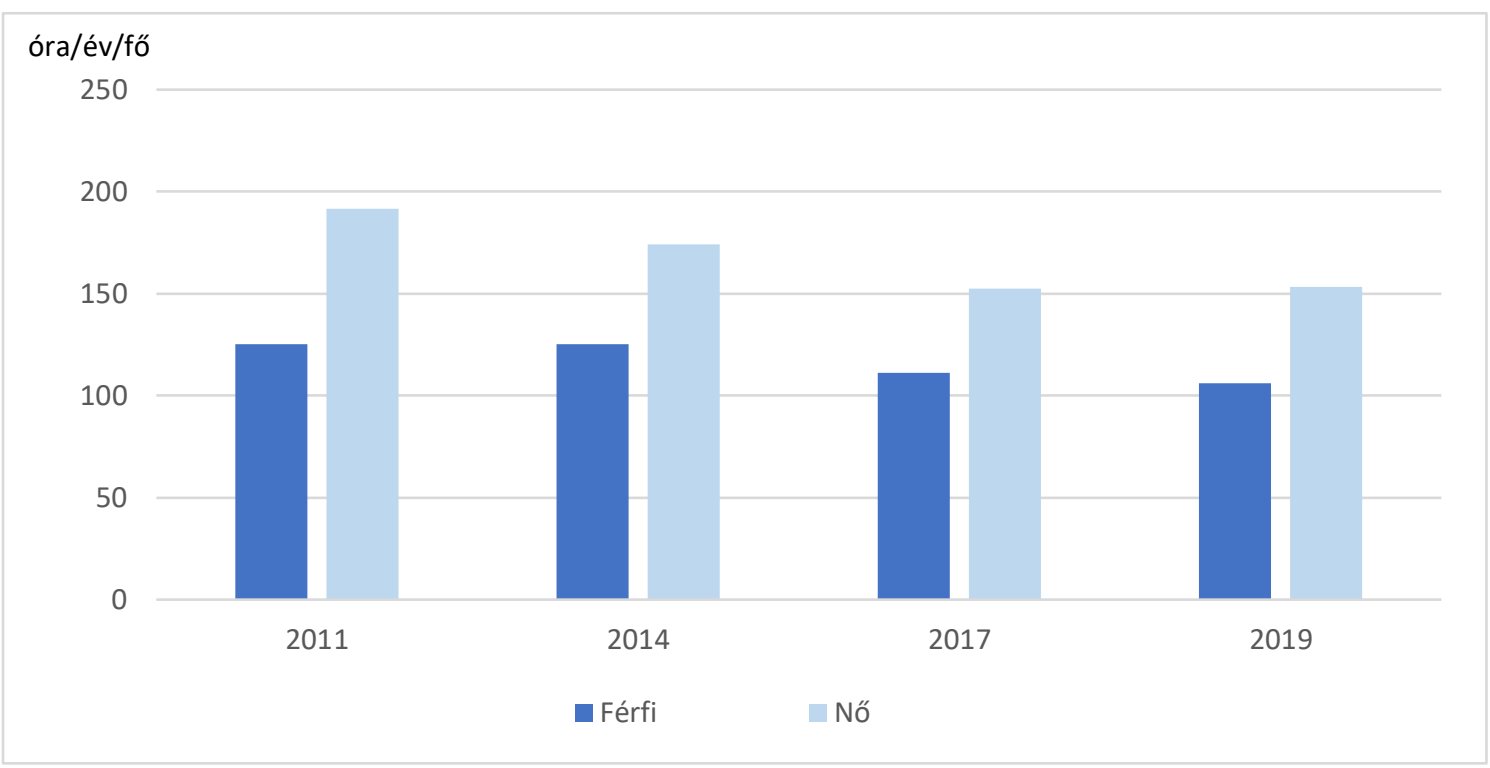

Forrás: KSH, Munkaerő-felmérés, Önkéntes munka c. kiegészítő felvételek 2011-2019.

Az önkéntesek által teljesített óraszám vizsgálatakor az életkor - az évtized elején és nyolc évvel később is - meghatározó tényezőnek bizonyult. Az önkéntességre fordított összes órából az egyre idősödő (ötéves) korcsoportokba tartozók órái egyre nagyobb arányt képviseltek, és mindkét évben a 60-64 évesek körében érték el a legmagasabb részarányt, vagyis az ilyen korúak fordítottak összességében a legtöbb időt önkéntes tevékenységekre. 2011-ben a 1519 évesek az összes óra mindössze 1,9 százalékát teljesítették, miközben a 60-64 évesek a 19 százalékát, 2019-ben a fiatalok az összes önkéntességre fordított időből 2,5 százalékkal részesedtek, miközben a 60-64 évesek 17,4 százalékkal. Az egy före jutó éves óraszám 2011ben a 60-64 évesek körében volt a legmagasabb, 271 óra, 2019-ben azonban a 65-69 évesek körében érte el a csúcsot 237,5 órával (16. ábra).

A legmagasabb iskolai végzettség és az önkéntesség közötti kapcsolatok vizsgálatakor azt tapasztaltuk, hogy 2011-ben is és 2019-ben is az érettségizett szakmai végzettséggel rendelkezők áldozták leginkább szabadidejüket ingyenes segítségnyújtásra (2011: 175,4 óra/év/fő; 2019: 143,5 óra/év/fő), de a diplomások körében is mindkét évben átlag feletti volt 
az önkéntes tevékenységekre fordított idő (2011: 160,3 óra/év/fő; 2019: 138,6 óra/év/fő). Érdemes ugyanakkor azt is megemlíteni, hogy jóllehet az önkéntesek által teljesített órák száma összességében 2019-ben az évtized elejihez képest jelentősen visszaesett, a jelenség a szakiskolát, szakmunkásképzőt végzettek mutatóiban nem igazán tükröződik. Az érettségivel nem rendelkező szakmai végzettségúek (szakmunkások) fajlagos mutatói ugyanis nagyon kis mértékben változtak. Esetükben az önkéntességre fordított éves átlagos óraszám a 2011. évi 141,8 óráról 2019-re mindössze 3,8 órával (138,0 órára) csökkent (17. ábra).

\section{6. ábra Az önkéntes munkát végzők éves átlagóraszáma korcsoportok szerint}

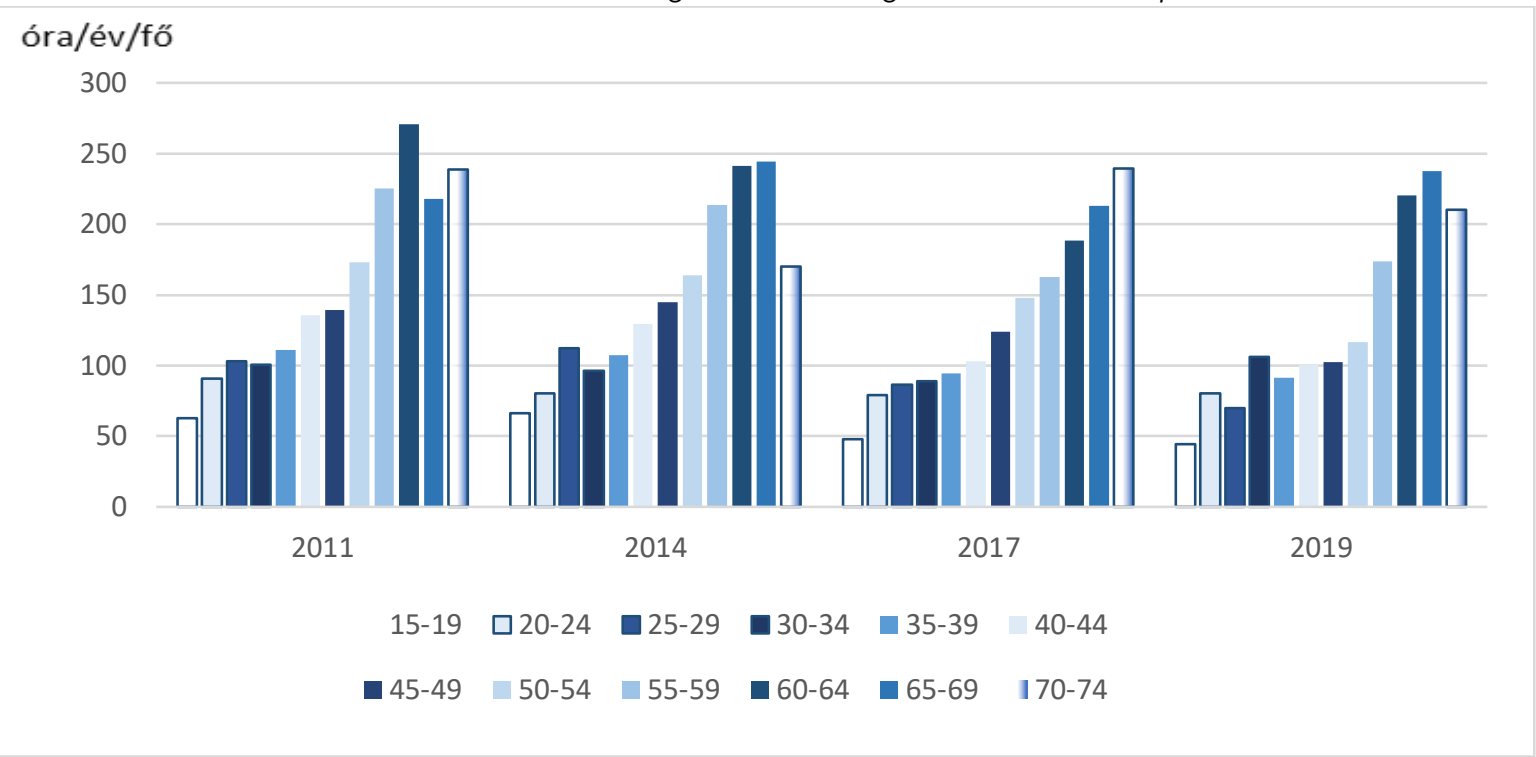

Forrás: KSH, Munkaerő-felmérés, Önkéntes munka c. kiegészítő felvételek 2011-2019.

\section{7. ábra Az önkéntes munkát végzők éves átlagóraszáma néhány jellemző szerint}

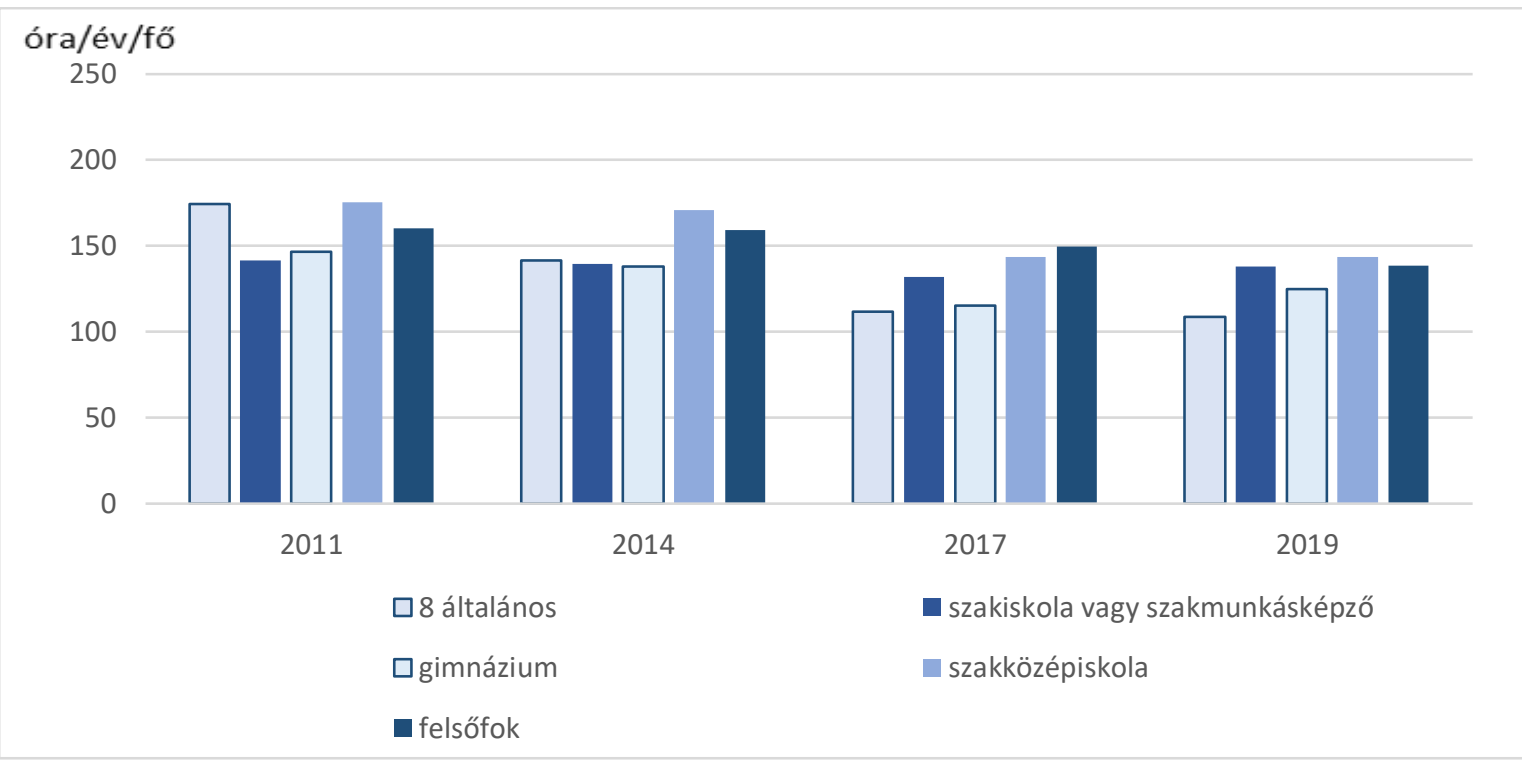

Forrás: KSH, Munkaerő-felmérés, Önkéntes munka c. kiegészítő felvételek 2011-2019. 
Összességében megállapítható, hogy a 2011. évi felvételhez képest 2019-re az önkéntesek száma ugyan 10,8 százalékkal nőtt, az önkéntes tevékenységgel töltött órák száma azonban 9,4 százalékkal csökkent (18. ábra).

18. ábra Az önkéntesek és az általuk teljesített órák aránya
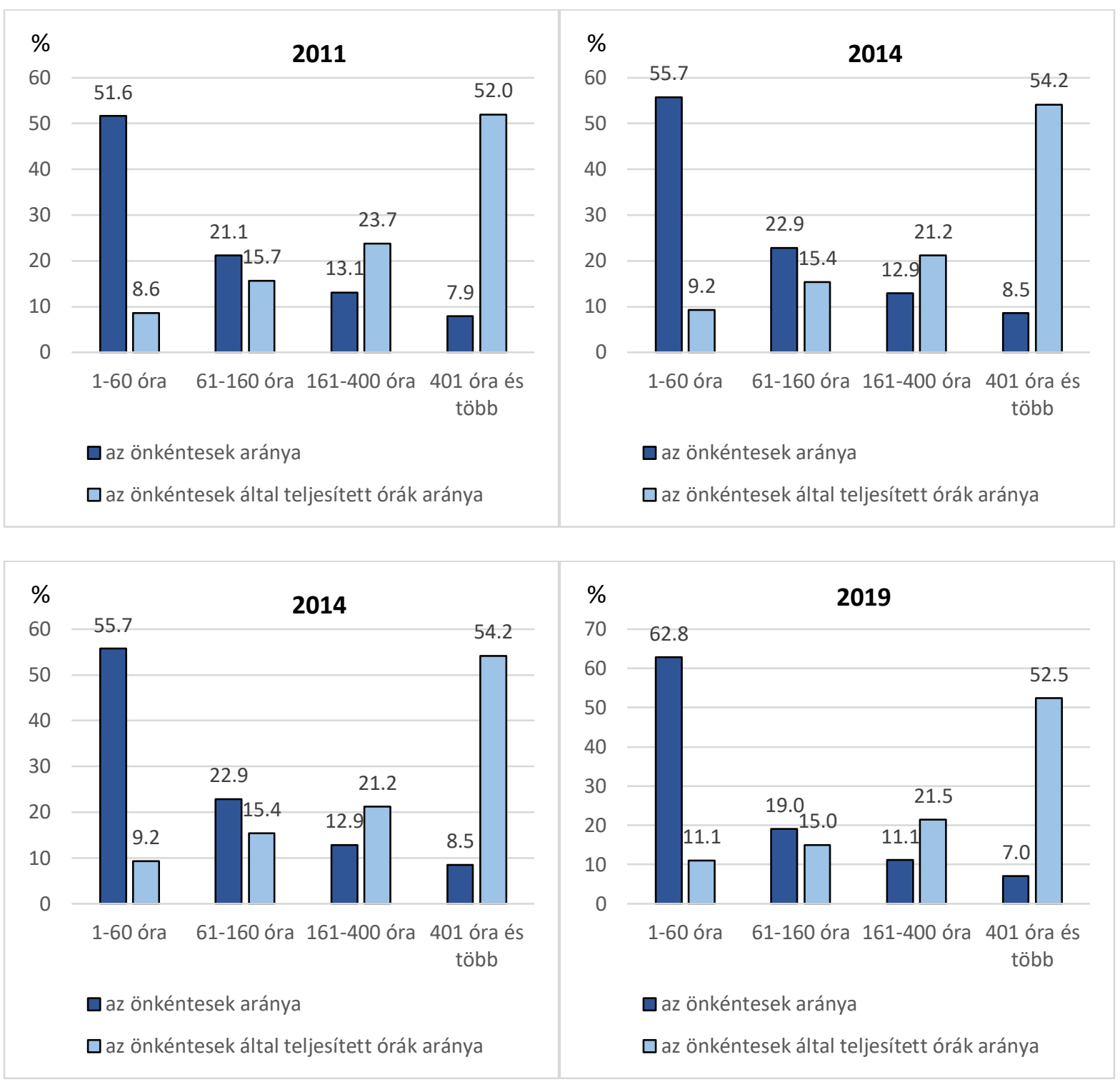

Forrás: KSH, Munkaerő-felmérés, Önkéntes munka c. kiegészítő felvételek 2011-2019.

Az önkéntesek segítéssel töltött idejüket illetően nem tekinthetők homogén csoportnak; meglehetősen sokan voltak, akik átlagosan heti 1-2 órát végeztek önkéntes munkát, és viszonylag kevesen azok, akik sok idejüket áldozták ilyen tevékenységre. A 2010-es évek elején az önkéntesek valamivel több, mint a fele (51,6 százalék) éves szinten legfeljebb 60 órát dolgozott, az általuk teljesített órák száma az összes (346 millió 146 ezer 472 óra) 8,6 százalékát tette ki. A skála másik végén az önkéntesek 7,9 százaléka éves szinten 400 órát 
meghaladó óraszámban végzett ilyen jellegű munkát. $A z$ ő teljesítményük az összes ledolgozott óra 52 százalékát tette ki. A 2019. évi felvétel eredményei azt mutatják, hogy az évi legfeljebb 60 órát segítő önkéntesek aránya 62,8 százalékra nőtt, és ők az összes önkéntes óra (313 millió 620 ezer 459 óra) 11,1 százalékát teljesítették. Ugyanakkor 7 százalékra csökkent azok aránya, akik éves szinten 400 óránál is többet segítettek önkéntes tevékenységükkel.

\section{AZ ÖNKÉNTES MUNKA ÉRTÉKELÉSÉNEK MÓDSZERE}

A GDP-számítások az adott társadalom teljes munkamennyiségének „csak” a piaci javakat előállító részét mutatják ki, ugyanakkor nagy értékű „piacon kívüli” gazdasági folyamatok a megfigyelés, kimutatás körén kívül eshetnek. A gazdaság összteljesítményének meghatározása során azonban kiemelkedő fontosságú, hogy ennek a nem piaci módon folyó és/vagy nem pénzben mért termelésnek a nagyságát és szerkezetét is számításba vegyük. Ennek egyik jellemző esete az önkéntes munka.

A továbbiakban a MEF kiegészítő felvételei alapján az önkéntes munka nagyságából, szerkezetéből kiindulva becsüljük meg az önkéntes munka értékét. A becslés során két alapvető problémát kell megoldani: mérni kell az önkéntes tevékenység nagyságát (volumenét), valamint pénzben ki kell fejezni annak értékét.

Az önkéntes munka mérete nehezen állapítható meg, mivel nem egyszerű sem a felhasznált források, sem az eredmények mérése. Mivel az önkéntes tevékenység által megtermelt javak és szolgáltatások piaci értékelésére nem kerül sor, eredménye nem kerül megmérettetésre a piacon, így nem rendelődik hozzá pénzben kifejezett érték. Továbbá, pénzbeli értékének meghatározása sem egyszerū, a felhasznált erőforrások ugyanis ingyenesek, jóllehet néha nagy szimbolikus értékkel rendelkezhetnek.

Általában a termelés mérésének legkézenfekvőbb módja az eredmény, a kibocsátás mérése. Tekintettel a kibocsátott áruk és szolgáltatások árainak ismeretéhez szükséges adatok hiányára, az önkéntes munka eredménye ily módon nehezen lett volna megbecsülhető. Ezért a munkaráfordítással való mérést alkalmaztuk a becslési eljárás során. A volument az önkéntes munkára fordított idővel becsültük, egy óra munkaráfordítást pedig annak helyettesítési költségével értékeltük. A piaci helyettesítési-költség módszer lényege, hogy az önkéntes munka eredményét vagy ráfordításait olyan értéken veszi figyelembe, amelyen azok a piacon 
megszerezhetők. Jelen esetben e módszer alkalmazása azt jelenti, hogy a felhasznált munka értékét egyenlőnek tekintjük az egyes tevékenységekre fordított időnek és - az adott tevékenységet a munkaerőpiacon végző - dolgozó órabérének a szorzatával. Attól függően, hogy kinek a bérét tekintjük helyettesítő piaci munkabérnek, különböző megoldások közül lehetséges választani.

\section{2. tábla Az önkéntes munka értékének kiszámítása}

\section{AZ ÖNKÉNTES MUNKÁT VÉGZŐK TEVÉKENYSÉGÉNEK BECSÜLT ÉRTÉKE}

A szervezeten keresztül (formális) önkéntes munkát végzők tevékenységei, valamint a közvetlen (informális) önkéntes munkát végzők tevékenységei becsült értékének összege.

\section{A közvetlen önkéntes munkát végzők tevékenységének becsült értéke az egy órára jutó munkajövedelem és az „Egyéb szolgáltatás" nemzetgazdasági ágban közvetlen önkéntes munkában ledolgozott éves óraszám szorzata. Az egy órára jutó munkajövedelem adatforrása: éves integrált gazdaságstatisztikai jelentések, és az éves adóbevallások adatai.}

\section{A közvetlen önkéntes munkában} ledolgozott órák száma: az „Önkéntes munka”című MEF kiegészítő felvételből származik.

A közvetlen önkéntes munka
nemzetgazdasági szintü értékének
becslése az „Egyéb szolgáltatás”
nemzetgazdasági ágban egy órára jutó
munkajövedelem, illetve a közvetlen
önkéntes munkában ledolgozott éves
óraszám alapján történt.
A közvetlen önkéntes munkát végzők
tevékenységének becsült értéke
demográfiai, illetve egyéb jellemzők
mentén a ledolgozott órák arányában
került felosztásra.

A szervezeten keresztül önkéntes munkát végzők tevékenységének becsült értéke az egy órára jutó munkajövedelem és a szervezeten keresztül önkéntes munkában ledolgozott éves óraszám szorzata.

Az egy órára jutó munkajövedelem adatforrása: az éves integrált gazdaságstatisztikai jelentések, és az éves adóbevallások adatai.

Vonatkozási kör: 1 fö feletti vállalkozások, valamennyi költségvetési és

társadalombiztosítási intézmény, valamint a kijelölt nonprofit szervezetek adatai.

Az egy órára jutó munkajövedelem adatok nemzetgazdasági ágak szerinti bontása szolgált az értékbecslés alapjául.

A szervezeten keresztül önkéntes munkában ledolgozott órák száma: az „Önkéntes munka”című MEF kiegészítő felvételből származik.

A szervezeten keresztül végzett önkéntes munka értékének becslése ágazati szinten történt, az egy órára jutó

munkajövedelem, illetve a ledolgozott éves óraszám alapján.

A nemzetgazdasági szintü érték a becsült nemzetgazdasági ág-értékek összege. A szervezeten keresztül önkéntes munkát végzők tevékenységének becsült értéke demográfiai, illetve egyéb munkaerő-piaci

jellemzők mentén a ledolgozott órák arányában került felosztásra. 
Az időráfordítás értékeléséhez a piacon múködő vállalkozásokban hasonló tevékenységet végzők keresetéből indultunk ki, különbséget téve az önkéntes munka formális és informális volta között. Előbbire - a piaci szektorhoz hasonlóan - a tevékenységi területek, a foglalkozások szerinti specializáltság inkább jellemző, ezért esetükben a piaci szektorban hasonló tevékenységet ellátók bérének alkalmazása mellett döntöttünk.

Az informális önkéntes munka értékének becslésére pedig - a hazai ilyen jellegű fizetett munka csekély elterjedtsége, valamint az ilyen keresetekre vonatkozó adatok bizonytalansága miatt - az általános helyettesítő bérek alkalmazása tűnt a legmegfelelőbbnek. Ezért az ágazati átlagos kereseteket vettük alapul, ami azt jelenti, hogy a piaci szektor szerinti súlyozást fogadtuk el az önkéntes munka esetében is.

\section{AZ ÖNKÉNTES MUNKA NOMINÁLIS ÉS GDP-HEZ MÉRT BECSÜLT ÉRTÉKE 2011-} 2019

Az önkéntes munka - a társadalmi értékén túl - jelentős hozzáadott értéket is képvisel. Pénzbeli értékének becslése azért is kiemelkedően fontos, mert általa arról is képet kaphatunk, mekkora gazdasági értéket képvisel az ország összteljesítményében. Az önkéntes tevékenység becsült értéke 2011-ben, 2014-ben, 2017-ben és 2019-ben is meghaladta a GDP 1 százalékát (19. ábra).

19. ábra Az önkéntes munka nominális és GDP-hez mért becsült értéke 2011-2019

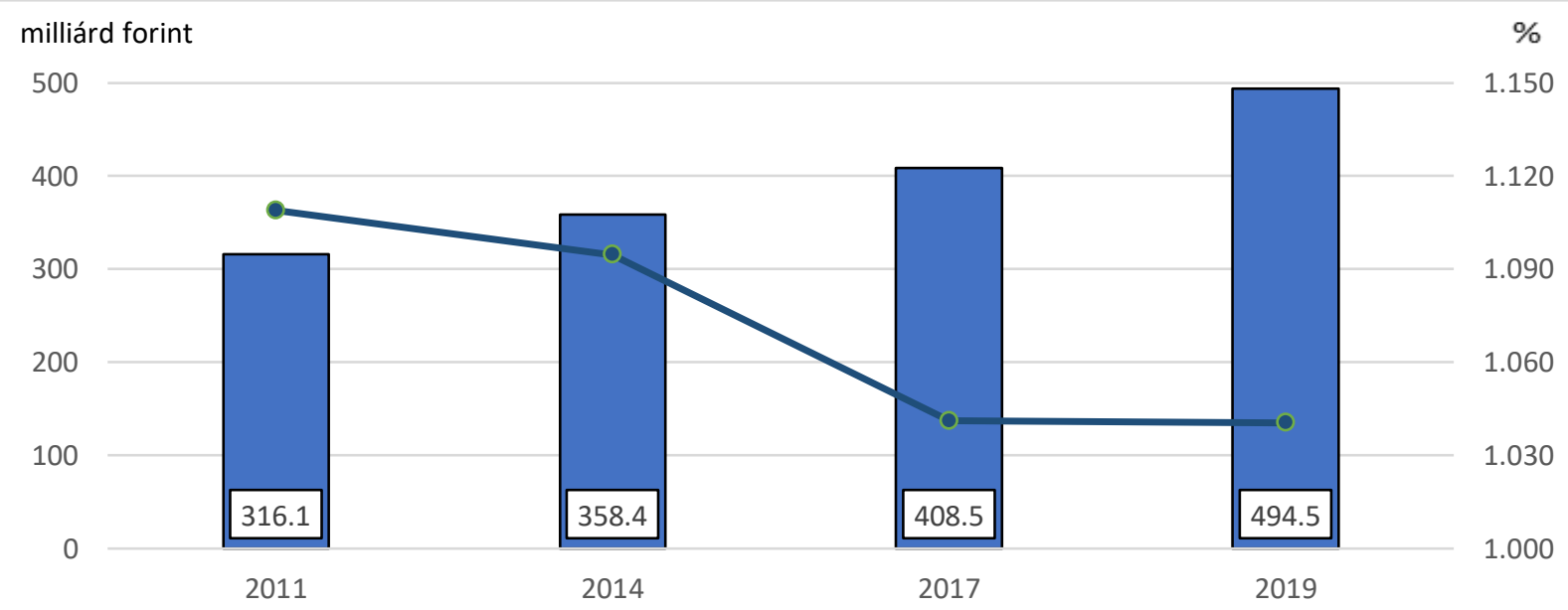

$\square$ Az önkéntes munka értéke (milliárd forint) —-Az önkéntes munka értéke a GDP százalékában (\%) 
Az önkéntes munka értéke 2011-ben 316,1 milliárd forintra volt becsülhető és - folyamatos növekedés mellett - az évtized végére több, mint a másfélszeresére, 494,5 milliárd forintra nőtt (19. ábra).

Ez a jelentős érték továbbra is túlnyomórészt az informális önkéntesek munkájának volt az eredménye, jóllehet az összértéken belüli arányok a formális önkéntesség javára változtak. 2011-ben az önkéntes munka összértékének 6,5 százaléka (20,5 milliárd forint) a szervezeten keresztül segítők munkájából származott, 2019-ben pedig a 8,0 százalékos részesedés 39,7 milliárd forintos értéket jelentett (20. ábra).

20. ábra Az formális és az informális önkéntes munka becsült értéke 2011-2019

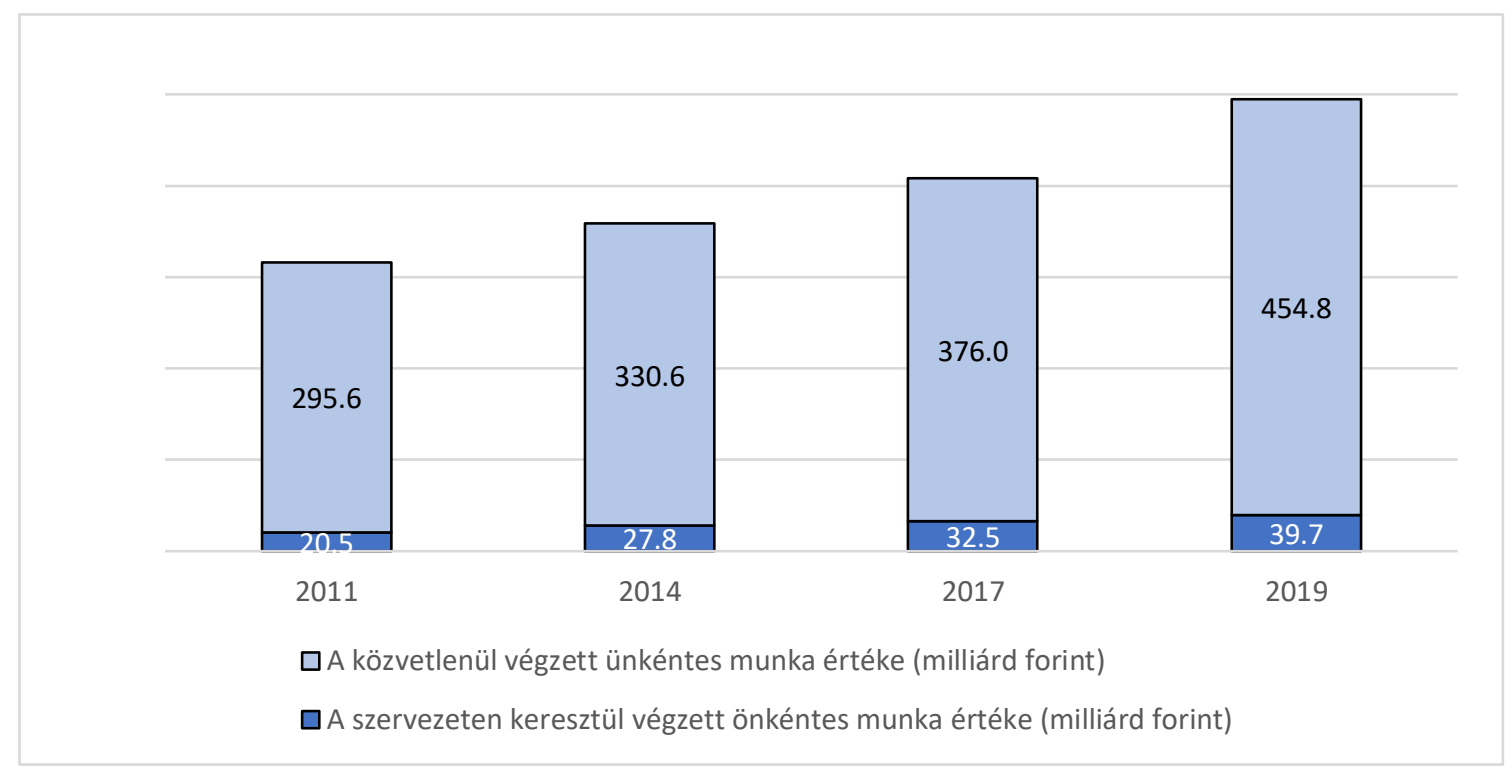

Forrás: Becslés a KSH, Munkaerő-felmérés, Önkéntes munka c. kiegészítő felvételei (2011-2019) alapján

\section{AZ ÖNKÉNTES MUNKA BECSÜLT ÉRTÉKE DEMOGRÁFIAI JELLEMZŐK MENTÉN}

Az önkéntes munka becsült értékéből a nők részesedése a 2010-es években meglehetősen stabilnak mondható, a mindenkori becsült érték több, mint 60 százaléka az ő tevékenységükből származott. 2011-ben 198,7 milliárd forintra volt tehető az általuk végzett munka értéke, 2019-ben pedig 312,1 milliárd forintra (ez utóbbi közel akkora értéket képviselt, mint a 2011. évi összes önkéntes által teljesített érték).

$A z$ ötéves korcsoportokra becsült értékeket vizsgálva megállapítható, hogy legnagyobb gazdasági hasznossága mind a négy alkalommal a 60-64 évesek önkéntes tevékenységének 
volt. 2011-ben közel 60 milliárd forint volt önkéntes munkájuk értéke, 2019-ben pedig már 84,7 milliárd forint.

21. ábra Az önkéntes munka becsült értéke demográfiai jellemzők mentén (milliárd Ft)

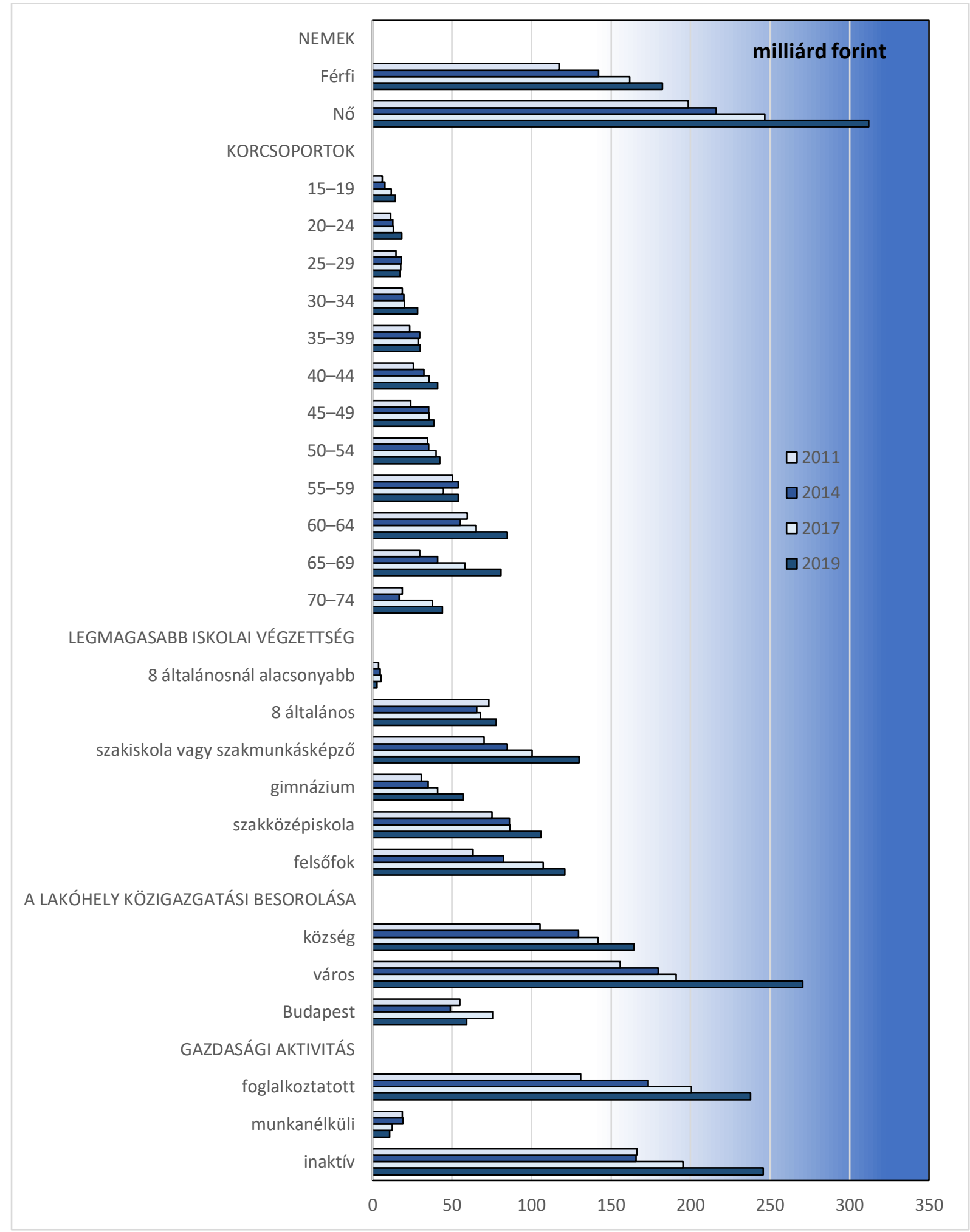

Forrás: Becslés a KSH, Munkaerő-felmérés, Önkéntes munka c. kiegészítő felvételei (2011-2019) alapján 
Az iskolai végzettség, mint az önkéntesség meghatározó tényezője, az értékadatokban is tükröződik. Különösen a szakmai végzettséggel rendelkezők áldozzák nagy számban és/vagy sok órában szabadidejüket önként, ingyenesen mások segítésére. 2019-ben az önkéntesek által végzett 494,5 milliárd forint háromnegyede szakmai végzettséggel rendelkező önkéntesek tevékenységéből származott.

Legnagyobb értéket 2019-ben is, a korábbi évekhez hasonlóan, a városlakók önkéntes tevékenysége képviselt. 2011-ben a kisebb-nagyobb városokban élők 155,8 milliárd forintnyi értéket képviselő önkéntes munkát végeztek, mely az összes érték 49,3 százalékát jelentette, miközben 2019-ben az általuk teljesített munka értéke 270,7 milliárd forintra, az összértékből a részesedés pedig 54,7 százalékra nőtt.

A következőkben az összefoglaló 3.-5.táblázatok a Munkaerő-felmérés 2011, 2014, 2017 és 2019 évi „Önkéntes munka" című kiegészítő felvételeinek létszám- és óraadatait, valamint a becsült értékadatokat tartalmazzák.

3. tábla Az önkéntesség föbb mutatói 2011

\begin{tabular}{|c|c|c|c|}
\hline \multirow{2}{*}{2011} & \multicolumn{3}{|c|}{ 15-74 évesek } \\
\hline & összesen & ebból: férfi & ebből: nő \\
\hline \multicolumn{4}{|l|}{ Önkéntesség } \\
\hline 15-74 éves népesség (fő) & 7578669 & 3639464 & 3939205 \\
\hline Önkéntes munkát végzők (fő) & 2153415 & 1005453 & 1147962 \\
\hline Önkéntességi arány (\%) & 28,4 & 27,6 & 29,1 \\
\hline \multicolumn{4}{|l|}{ Az önkéntesek órái } \\
\hline Ledolgozott órák (óra) & 346146472 & 126091062 & 220055410 \\
\hline Éves egyenértékes létszám (állás) & 189665 & 69104 & 120561 \\
\hline Éves átlagóraszám (óra/fő/év) & 160,7 & 125,4 & 191,7 \\
\hline Éves medián óraszám (óra/fő/év) & 60,0 & 50,0 & 71,7 \\
\hline Becsült érték (forint) & 316075922079 & 117413636149 & 198662285930 \\
\hline 1 fő önkéntes munkát végzőre jutó érték (ft/fő & 146779 & 116777 & 173057 \\
\hline
\end{tabular}

4. tábla Az önkéntesség föbb mutatói 2014

\begin{tabular}{|c|c|c|c|}
\hline \multirow{2}{*}{2014} & \multicolumn{3}{|c|}{ 15-74 évesek } \\
\hline & Összesen & ebből: férfi & ebből: nő \\
\hline \multicolumn{4}{|l|}{ Önkéntesség } \\
\hline 15-74 éves népesség (fő) & 7446056 & 3589700 & 3856356 \\
\hline Önkéntes munkát végzők (fő) & 2557447 & 1206481 & 1350966 \\
\hline Önkéntességi arány (\%) & 34,3 & 33,6 & 35,0 \\
\hline \multicolumn{4}{|l|}{ Az önkéntesek órái } \\
\hline Ledolgozott órák (óra) & 386731112 & 151238692 & 235492420 \\
\hline Éves egyenértékes létszám (állás) & 189519 & 69183 & 120335 \\
\hline Éves átlagóraszám (óra/fő/év) & 151,2 & 125,4 & 174,3 \\
\hline Éves medián óraszám (óra/fő/év) & 50,0 & 48,0 & 60,0 \\
\hline Becsült érték (forint) & 358393192361 & 142086874393 & 216306317969 \\
\hline 1 fő önkéntes munkát végzőre jutó (ft/fő/év) & 140137 & 117770 & 160112 \\
\hline
\end{tabular}


5. tábla Az önkéntesség föbb mutatói 2017

\begin{tabular}{|c|c|c|c|}
\hline \multirow{2}{*}{2017} & \multicolumn{3}{|c|}{ 15-74 évesek } \\
\hline & összesen & ebből: férfi & ebből: nő \\
\hline \multicolumn{4}{|l|}{ Önkéntesség } \\
\hline 15-74 éves népesség (fő) & 7263932 & 3499340 & 3764592 \\
\hline Önkéntes munkát végzők (fő) & 2668243 & 1251635 & 1416608 \\
\hline Önkéntességi arány (\%) & 36,7 & 35,8 & 37,6 \\
\hline \multicolumn{4}{|l|}{ Az önkéntesek órái } \\
\hline Ledolgozott órák (óra) & 353793797 & 138814217 & 214979580 \\
\hline Éves egyenértékes létszám (állás) & 193230 & 75814 & 117416 \\
\hline Éves átlagóraszám (óra/fő/év) & 133,0 & 111,3 & 152,2 \\
\hline Éves medián óraszám (óra/fő/év) & 40,0 & 33,3 & 40,0 \\
\hline Becsült érték (forint) & 408472662770 & 161629667663 & 246842995106 \\
\hline 1 fő önkéntes munkát végzőre jutó (ft/fö/év) & 153087 & 129135 & 174249 \\
\hline
\end{tabular}

6. tábla Az önkéntesség föbb mutatói

\begin{tabular}{|c|c|c|c|}
\hline \multirow{2}{*}{2019} & \multicolumn{3}{|c|}{ 15-74 évesek } \\
\hline & összesen & ebből: férfi & ebből: nő \\
\hline \multicolumn{4}{|l|}{ Önkéntesség } \\
\hline 15-74 éves népesség (fő) & 7196366 & 3483633 & 3712733 \\
\hline Önkéntes munkát végzők (fő) & 2385742 & 1087651 & 1298091 \\
\hline Önkéntességi arány (\%) & 33,2 & 31,2 & 35,0 \\
\hline \multicolumn{4}{|l|}{ Az önkéntesek órái } \\
\hline Ledolgozott órák (óra) & 313620459 & 114941917 & 198678542 \\
\hline Éves egyenértékes létszám (állás) & 177055 & 64879 & 112176 \\
\hline Éves átlagóraszám (óra/fő/év) & 131,8 & 106,0 & 153,5 \\
\hline Éves medián óraszám (óra/fő/év) & 40,0 & 36,7 & 45,0 \\
\hline Becsült érték (forint) & 494482576530 & 182404807809 & 312077767179 \\
\hline 1 fő önkéntes munkát végzőre jutó (ft/fő/év) & 207266 & 167705 & 240413 \\
\hline
\end{tabular}

\section{ÖSSZEGZÉS - FŐBB MEGÁLLAPÍTÁSOK AZ ÖNKÉNTESSÉG ALAKULÁSÁRÓL A 2010- ES ÉVEKBEN}

Magyarországon egyre elterjedtebb az önkéntes munka. 2011-ben a 15-74 évesek 28,4 százaléka nyilatkozott úgy, hogy a felvételt megelőző 12 hónap során végzett valamiféle önkéntes tevékenységet, 2019-ben pedig már egyharmaduk, mintegy 2 millió 386 ezer fő számolt be ilyen tevékenységről.

Nyolc év alatt az önkéntesek száma 232 ezer fővel nőtt; ezen belül a közvetlenül segítők száma, illetve a szervezeten keresztül önkéntes munkát végzőké közel fele-fele arányban emelkedett, miközben az önkéntesség mindkét formájában segítők száma nem igazán változott. 
Az önkéntesek túlnyomó többsége - tízből kilenc - továbbra is kizárólag közvetlenül segített ingyenes munkájával, a szervezett keretek között végzett önkéntes munka - növekedése ellenére - még mindig nem igazán elterjedt.

A nők továbbra is nagyobb számban és arányban kapcsolódtak be az önkéntes tevékenységekbe, mint a férfiak, és az évtized elejéhez képest már a formális önkéntesek között is több nőt találunk, mint férfit.

Annak ellenére, hogy a magyarországi önkéntesség továbbra is kissé elöregedő korstruktúrát tükröz, a kiegyenlítődés irányába történtek elmozdulások. Az önkéntes munka vállalása - a 15-19 éves korcsoport speciális helyzetétől eltekintve - legmagasabb arányban az 60-64 éveseket jellemezte. A 15-19 éves korcsoportban megfigyelhető átlag feletti és egyben legmagasabb arány elsősorban az iskolai közösségi szolgálat kiterjesztésének a következménye.

Az önkéntes segítők aránya az iskolázottsággal növekszik, és a diplomások körében a legmagasabb.

A települési lejtő mentén nő az önkéntesek aránya; a Budapesten élők továbbra is jóval az átlag alatti arányban végeztek önkéntes tevékenységet, miközben a többi városban továbbra is az országos átlagot kismértékben meghaladó volt az önkéntesség. Az ingyenes, önzetlen segítségnyújtás a községekben, kis lélekszámú településeken élőkre volt jellemző, hasonlóan az évtized elején tapasztaltakhoz.

Az önkéntesség leggyakoribb megjelenési formái változatlanul a házi- és házkörüli munka, az ügyintézés és vásárlás, a gyermekfelügyelet, gyermekgondozás, illetve a betegápolás, idősgondozás voltak. Az önkéntesek által - rendszeresen vagy alkalmanként - végzett összes tevékenység háromnegyedét ezek a tevékenységek alkották.

A közvetlenül végzett önkéntes tevékenységek kedvezményezettjeinek száma - az évtized elejéhez hasonlóan 2019-ben is - másfélszeresen haladta meg a közvetlen önkéntesek számát. A kedvezményezettek struktúrája sem igazán változott; fele arányban a háztartáson kívül élő családi, rokoni körhöz tartozott, egyötödük pedig a baráti körből került ki.

Az önkéntesek motivációja leginkább a másokon való segítségnyújtás öröme volt, azzal az általánosnak tekinthető meggyőződéssel, hogy a gyerekeken, öregeken, súlyos betegeken segíteni erkölcsi kötelesség. 
A hagyományos önkéntesség mellett fóként a fiatalokat jellemzi az elmozdulás az új típusú önkéntesség irányába. A szaktudás, a gyakorlati tapasztalat megszerzése, a kapcsolati háló bővítése és olyan - ezekhez hasonló, a tudásalapú, információs társadalomra jellemző társadalmi értékek kerülnek a középpontba, mint például az élethosszig tartó tanulás.

Az önkéntesek száma 2011 és 2019 között több, mint 10 százalékkal nőtt, az önkéntes tevékenységgel töltött órák száma azonban közel 10 százalékkal csökkent.

$A z$ önkéntesek segítéssel töltött idejüket illetően nem tekinthetők homogén csoportnak; meglehetősen sokan vannak, akik átlagosan heti 1-2 órát végeznek önkéntes munkát, és viszonylag kevesen azok, akik sok idejüket áldozzák mások segítésére.

Az önkéntes munka értéke 2011-ben 316,1 milliárd forintra volt becsülhető és - folyamatos növekedés mellett - az évtized végére több, mint a másfélszeresére, 494,5 milliárd forintra nőtt. De hogy valójában mekkora is a gazdasági értéke, azt leginkább GDP-hez mért arányában tudjuk értékelni. A 2010-es években a magyarországi önkéntesség a GDP 1 százalékát meghaladó értéket képviselt.

„Az önkéntes tevékenység az egész társadalmi, gazdasági életet behálózza. A társadalmi beilleszkedés egyik eszközeként különösen fontos, hogy az egyének, a társadalom számára értékké váljon, és olyan önkéntességi kultúra valósuljon meg, amely minden korosztály számára közvetíti a társadalmi felelősségvállalás, a közösségi szerepvállalás, a kompetenciakészségek elsajátításának jelentőségét. Az önkéntes tevékenység egy lehetőség arra, hogy bárki, nemtől, kortól, iskolai végzettségtől, társadalmi-gazdasági háttértől, nemzetiségtől, vallástól függetlenül közremüködjön a pozitív változás elérése érdekében. A polgárok egyéni felelősségvállalásukkal, így az önkéntességgel is hozzájárulhatnak a társadalmi összetartozás erősítéséhez. A hátrányos helyzetű csoportok önkéntes segítése hozzájárul e csoportok helyzetének javításához, emellett pedig kapcsolatot teremt az eltérő környezetben élő emberek között, erősítve a társadalmi szolidaritást. A klubokban, egyletekben, illetve hasonló társadalmi intézményekben vállalt önkéntes tevékenység növekedése szintén a társadalom tagjai közötti kapcsolatokat, a közösségi összetartozást erősíti." (KSH, A fenntartható fejlődés indikátorai Magyarországon, 2018. 96.o.) 


\section{IRODALOM}

A fenntartható fejlődés indikátorai Magyarországon, 2018. Budapest: Központi Statisztikai Hivatal 2019. https://www.ksh.hu/docs/hun/xftp/idoszaki/fenntartfejl/fenntartfejl18.pdf

Központi Statisztikai Hivatal 2011. évi Munkaerő-felmérés III. negyedévi, az „Önkéntes munka” c. kiegészítő felvétel adatai

Központi Statisztikai Hivatal 2014. évi Munkaerő-felmérés I. negyedévi, az „Önkéntes munka” c. kiegészítő felvétel adatai.

Központi Statisztikai Hivatal 2017. évi Munkaerő-felmérés I. negyedévi, az „Önkéntes munka” c. kiegészítő felvétel adatai.

Központi Statisztikai Hivatal 2019. évi Munkaerő-felmérés I. negyedévi, az „Önkéntes munka” c. kiegészítő felvétel adatai.

Váradi Rita (2017): Az önkéntes munka jellemzői a munkaerő-felmérés alapján. In. Háztartási munka, önkéntes munka, láthatatlan munka I. A háztartási és az önkéntes munka mérése, elemzése (szerk.: Janák K.- Szép K - Tokaji Kné). Budapest: Központi Statisztikai Hivatal pp. 66-89.

https://www.ksh.hu/docs/hun/xftp/idoszaki/pdf/lathatatlan_munka_1.pdf 